\section{Kvalita vody a stav společenstev vodních bezobratlých $v$ drobných tocích Prahy}

\author{
PAVEL KOŽENÝ, HANA JANOVSKÁ, JITKA SVOBODOVÁ \\ Klíčová slova: Praha - vodní toky - kvalita vody - \\ ekologický stav - vodní bezobratlí - makrozoobentos - raci
}

\section{SOUHRN}

Cílem této studie bylo zpracování hodnocení ekologického stavu drobných toků na území hlavního města Prahy postupem analogickým s hodnocením vodních útvarů podle Směrnice 2000/60/ES. Pro výzkum bylo vybráno celkem osm lokalit na sedmi vodních tocích (potoky Šárecký, Dalejský, Radotínský, Libušský, Kunratický, Botič a Rokytka) s tím, že do výběru byly zahrnuty př́rodě blízké i různým způsobem revitalizované úseky. Na vybraných lokalitách probíhalo od května 2017 roční vzorkování chemických ukazatelů a standardní multihabitatovou metodou byly odebrány vzorky vodních bezobratlých (makrozoobentosu). Údaje o kvalitě vody a společenstvech makrozoobentosu byly doplněny o astakologický průzkum výskytu původních i nepůvodních druhů raků. Ten byl proveden na Šáreckém, Říčanském, Radotínském, Dalejském potoce a na Rokytce.

Hodnocení fyzikálně-chemických parametrů zařadilo všechny lokality do středního a horšího ekologického stavu. Nejhorší výsledky přineslo vyhodnocení celkového a fosforečnanového fosforu, kde spadaly do kategorie středního a horšího stavu všechny lokality. Na základě hodnocení společenstva makrozoobentosu byly do středního ekologického stavu zařazeny lokality Šárecký potok, Rokytka pod Hořejším rybníkem, Radotínský a Libušský potok. Dalejský potok, Kunratický potok, Rokytka nad Hořejším rybníkem a Botič byly zatříděny do poškozeného ekologického stavu. Žádná ze sledovaných lokalit tak nedosáhla dobrého stavu. Hlavním důvodem vyhodnocené špatné kvality vody na drobných tocích Prahy bylo znečištění živinami, predevším fosforem, který je prríčinou eutrofizace vodních ekosystémů. Špatnou kvalitou vody jsou zjevně limitována i společenstva vodních bezobratlých v revitalizovaných i prírodě blízkých vodních tocích. Na Dalejském potoce na horním okraji obce Řeporyje byl prokázán výskyt ohroženého raka bahenního (Astacus leptodactylus). Negativním zjištěním je zánik populace kriticky ohroženého raka kamenáče (Austropotamobius torrentium) na Radotínském potoce. Pravděpodobnou přičinou bylo silné znečištění komunální odpadní vodou a následně zjištěná nákaza račím morem. Při průzkumu nebyli nalezeni žádní jedinci nepůvodních druhů raků.

\section{Water Quality and State of Aquatic Invertebrate Populations in Small Watercourses in Prague}

\author{
PAVEL KOŽENÝ, HANA JANOVSKÁ, JITKA SVOBODOVÁ \\ Keywords: Prague - watercourses - water quality - \\ ecological status - aquatic invertebrates - macrozoobenthos - crayfish
}

\section{ABSTRACT}

The aim of this paper has been to evaluate the ecological status of small watercourses in the capital city of Prague by analogy to the evaluation of water bodies pursuant to Directive 2000/60/EC. A total of eight sites were selected at seven watercourses (Šárecký, Dalejský, Radotínský, Libušský, Kunratický, Botič and Rokytka Streams). Both sections that are semi-natural and those that have been restored in various ways were selected. From May 2017 onwards, annual sampling of chemical indicators took place in selected sites and a standard multihabitat method was used to take samples of aquatic invertebrates (macrozoobenthos). Data related to water quality and macroinvertebrates populations were complemented with astacological research of the presence of native and alien crayfish species, which took place in Šárecký, Říčanský, Radotínský, Dalejský and Rokytka Streams.

On the basis of evaluated physicochemical parameters, all the above sites were classified as moderate and worse ecological status. An evaluation of total and phosphate phosphorus yielded the worst results and all the sites were classified as moderate and worse status. An evaluation of macroinvertebrates populations yielded the following results: the sites at Šárecký Stream, Rokytka below Hořejší Pond, Radotínský Stream and Libušský Stream were classified as moderate ecological status whereas Dalejský Stream, Kunratický Stream, Rokytka above Hořjší Pond and Botič Stream were classified as poor ecological status. None of the evaluated sites thus reached good status. The main reason for the evaluated poor water quality of small watercourses in Prague is pollution by nutrients, in particular phosphorus, which causes eutrophication of aquatic ecosystems. Poor water quality clearly also limits populations of aquatic invertebrates in restored and semi-natural watercourses. The presence of endangered narrow-clawed crayfish (Astacus leptodactylus) was established in Dalejský Stream at the upper boundary of the Reporyje municipality. A negative finding is extinction of the population of critically endangered stone crayfish (Austropotamobius torrentium) in Radotínský Stream. This extinction was probably caused by strong municipal waste water pollution and by subsequently established crayfish plague. No alien crayfish population specimens were found during the research. 


\section{ÚVOD}

Na území Prahy se nachází 357 km drobných vodních toků 1. až 4. rádu dle Strahlera. Jejich převážná většina je také hlavním městem Prahou (HMP) spravována. Od roku 2000 provádí HMP systematické měření a vyhodnocování fyzikálně-chemických a chemických parametrů kvality vody na 16 potocích v 38 profilech a $v 55$ vodních nádržích [1]. Měření se koná jednou měsičně v blízkosti ústí větších potoků a jednou za dva měsíce na zbývajících 33 profilech. Souhrnné vyhodnocení je prováděno do tříd jakosti povrchových vod podle normy ČSN 757221 [2].

Pravidelný monitoring biologických složek není HMP realizován. Výzkum biologických složek je bud’ predmětem samostatných zakázek, nebo probíhá v rámci činnosti výzkumných institucí. Především potok Botič je dlouhodobě studován pracovištěm ČVUT V Praze, jehož pracovníci se mimo jiné zabývají hodnocením vodních bezobratlých (makrozoobentosu) [3-6]. Ostatní publikované údaje o vodních bezobratlých z území Prahy jsou sporadické [7]. Makrozoobentos prítom tvoři jednu z hlavních biologických složek vodního prostředí, jíž je v České republice dlouhodobě věnována systematická pozornost. Jedná se totiž o široce rozširiřenou a taxonomicky rưznorodou skupinu organismů dosahujících vysokých početností, které mají rozdílné nároky na prostředí a obvykle dobré bioindikační schopnosti - tedy schopnosti reflektovat podmínky prostředí, v němž se nacházejí, a jejich změny. Této schopnosti je možno využít právě k hodnocení míry ovlivnění různými negativními antropogenními vlivy nebo naopak nápravnými opatřeními, a proto je využívána pro hodnocení ekologického stavu vod, zejména vod tekoucích. Prístupy k tomuto hodnocení jsou definovány Rámcovou směrnicí o vodách (RSV) [8]. Ekologický význam společenstva makrozoobentosu v prostředí vodního toku je zásadní. Jako součást potravního řetězce mají jednotlivé taxony rưzné potravní strategie [9]. Nacházíme zde mimo jiné spásače a seškrabávače živící se např. na nárostech řas, sběrače, kouskovače podílející se na rozkladu např. spadaného listí, filtrátory živící se jemnou partikulovanou hmotou i dravce. Zároveň je makrozoobentos důležitou složkou potravy rybí obsádky.

Jiní autoři se zabývali na území Prahy též výskytem raků [10], což je v městském prostředí téma atraktivní a závažné z důvodu ochrany populací původních raků a naopak omezení šíření raků nepůvodních. Původní evropské raky (rak říční, rak bahenní a rak kamenáč), jako největší zástupce makrozoobentosu, Ize považovat za tzv. deštníkové druhy, nebot' jejich ochranou je zajištěna i ochrana celé řady druhů sdílejících s raky stejný biotop. Raci nejsou potravně specializováni a živí se rozmanitou stravou rostlinného i živočišného původu. Invazní druhy raků (především rak signální a rak pruhovaný), na rozdíl od původních raků, jsou daleko agresivnější k ostatním vodním živočichům. Mají mnohem vyšší rozmnožovací schopnosti (rozmnožují se častěji a mají vyšší počet potomků), a dokážou tak v krátké době zcela zdecimovat jak faunu, tak i flóru $\checkmark$ dané lokalitě. Kromě toho jsou přenašeči račího moru, onemocnění, které naše původní druhy raků usmrcuje a jehož původcem je plísni podobný patogen Aphanomyces astaci. Nepůvodní raci jsou tímto patogenem často nakaženi, avšak vůči onemocnění jsou rezistentní. Výskyt invazních raků proto dokáže v krátké době způsobit vymizení celé původní populace našich raků v lokalitě a narušit stabilitu vodního ekosystému [11].

Dva největší pražské potoky, Botič a Rokytka, jsou vymezeny jako vodní útvary ve smyslu RSV [8]. Státní podnik Povodí VItavy provádí na jejich reprezentativních profilech pravidelný monitoring, ze kterého pak vyhodnocuje ekologický stav vodního útvaru [12]. Takto jsou však hodnoceny pouze dva z mnoha vodních toků, reprezentativní profily jsou navíc umístěny na okraji Prahy, ještě před hlavními vlivy pražské aglomerace.

\section{INTRODUCTION}

According to the Strahler method, there are $357 \mathrm{~km}$ of small order 1 to 4 streams in Prague. A vast majority of them is administered by the capital city of Prague. Since 2000, Prague has been doing systematic measurement and evaluation of physicochemical and chemical parameters of water quality of 16 streams in 38 profiles and 55 water reservoirs [1]. Measurement takes place once a month close to the mouth of larger streams and once every two months in the remaining 33 profiles. Based on an overall evaluation, the above are classified into surface water quality classes pursuant to the ČSN Technical Standard 757221 [2].

Prague does not regularly monitor biological quality elements. Research of biological is either a subject of individual contracts or it is done by research institutions. Botič Stream in particular has been examined long-term by the Czech Technical University in Prague, which also evaluates aquatic invertebrates (macrozoobenthos) [3-6]. Other published data related to aquatic invertebrates in Prague are sporadic [7]. However, macroinvertebrates is one of the main biological components of the aquatic environment that has been systematically researched in the Czech Republic. Macroinvertebrates is a widespread and taxonomically diverse group of organisms that are very abundant, have different demands for the environment they live in and usually good bioindicator abilities, i.e., abilities to reflect the conditions of the environment they live in and also changes thereof. This capability may be used to evaluate the degree to which they are affected by various negative anthropogenic impacts or on the contrary remedial measures and that is why it is used to evaluate the ecological status of water, especially running water. Approaches to this evaluation are defined by the Water Framework Directive (WFD) [8]. The environmental significance of macroinvertebrates populations in watercourses is crucial. As part of the food chain, the individual taxons have various feeding strategies [9]. Among others, there are those that graze and scrape, feeding on a growth of algae, those that collect and cut, taking part in the decomposition of fallen leaves for example, then there are filter feeders who feed on fine particulate matter and also predators. At the same time, macroinvertebrates is an important component of what the fish stock feeds on.

Other researchers also studied the presence of crayfish in Prague [10], which is an attractive and very serious topic in urban environment with regard to the protection of native crayfish populations and limiting the spread of alien crayfish. Native crayfish (Noble crayfish, Narrow-clawed crayfish and stone crayfish) as the largest macroinvertebrates representatives may be regarded as umbrella species whose protection safeguards the protection of a whole range of other species who share the same biotope with crayfish. Crayfish do not feed only on specific foods but rather feed on diverse plants and animals. As opposed to native crayfish, invasive crayfish species (in particular signal crayfish and spinycheek crayfish) are far more aggressive to other aquatic animals. They have a far greater reproductive ability (they reproduce more often and have more offspring) and are thus able to completely destroy both the fauna and flora in a given site in a short period of time. Besides, they are carriers of crayfish plague, which is a disease that kills native crayfish species and is caused by a mold-like pathogen Aphanomyces astaci. Alien crayfish are often infected with this pathogen but are resistant to the disease. The presence of invasive crayfish can thus lead to the extinction of the whole population of native crayfish in a site and disrupt the stability of the aquatic ecosystem [11].

Two largest Prague Streams, Botič a Rokytka, are defined as water bodies within the meaning of the WFD [8]. State-owned enterprise Povodí VItavy carries out regular monitoring of their representative profiles based on which it evaluates the ecological status of these water bodies [12]. However, only two out of numerous watercourses are evaluated in this way and besides that the representative profiles are located on the outskirts of Prague before the main impacts of the Prague agglomeration. 
V letech 2017-2018 probíhaly v rámci projektu VODA PRO PRAHU na několika lokalitách pražských potoků experimentální práce. Jejich cílem bylo zlepšení ekologického stavu potoků pomocí zvýšení jejich tvarové členitosti a nabídky stanovišt pro vodní organismy [13]. V rámci projektu byla získána data o fyzikálně-chemických a chemických parametrech, společenstvech bentických bezobratlých, včetně výskytu raků ze sedmi větších potoků v Praze.

Cílem této práce je poskytnout informaci, jež v rámci Prahy dosud chyběla: zpracovat hodnocení ekologického stavu drobných toků analogické s postupy RSV [14, 15]. Zároveň chceme doplnit údaje o kvalitě vody z míst, která nejsou předmětem dlouhodobého monitoringu. $V$ této souvislosti zařazujeme také zjištění o výskytu raků, jejichž ochrana je aktuální a s kvalitou vody úzce souvisí.

\section{LOKALITY A METODY}

\section{Lokality}

Pro výzkum bylo vybráno celkem osm lokalit na sedmi vodních tocích na území hlavního města Prahy. Jejich polohu a základní charakteristiky znázorňuje schématická mapka na obr. 1 a tab. 1.

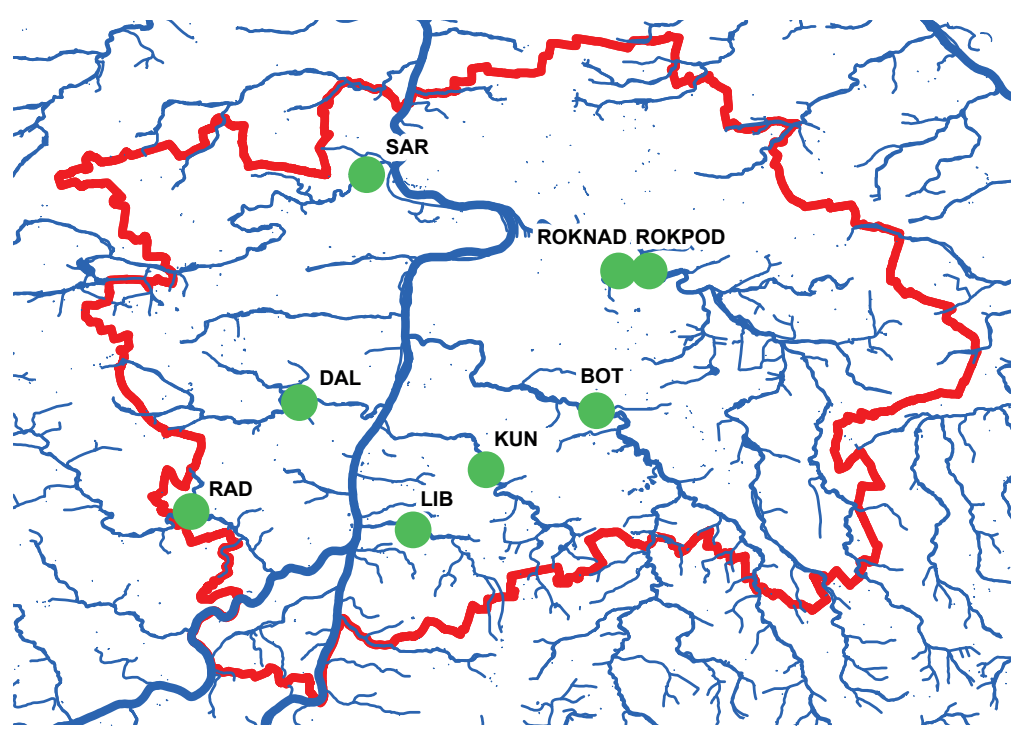

Obr. 1. Schématické znázornění lokalit drobných vodních toků na území hlavního města Prahy

Vybrané úseky na Botiči, Radotínském, Libušském a Kunratickém potoce Ize charakterizovat jako neupravené vodní toky v př́rodě blízkém stavu. Jejich okolí je tvořeno lesem nebo extenzivně využívanými zemědělskými plochami se zachovalým břehovým porostem dřevin.

Další čtyři lokality byly vybrány na úsecích toků, kde proběhla v nedávných letech revitalizace koryta. Rokytka nad Hořejším rybníkem a Šárecký potok na Žežulce jsou komplexně revitalizovanými vodními toky. Dalejský potok na místě bývalého klukovického koupaliště byl rozvolněn a získal široké štěrkové koryto. Rokytka pod Hořejším rybníkem má balvany opevněné, zahloubené kapacitní koryto, které však bylo v rámci územních možností rozčleněno kamenivem na peřejnaté úseky. Ve všech prípadech je okolí revitalizovaných úseků tvořeno prírodní rekreační plochou. Podrobný popis i bohatou obrazovou dokumentaci provedených revitalizací lze nalézt na webových stránkách „Pražská příroda“ [1]. Revitalizační úpravy byly na těchto lokalitách dokončeny dva až čtyři roky před zahájením vzorkování.
In 2017-2018, experimental work took place in several sites of Prague Streams within the "VODA PRO PRAHU" ["WATER FOR PRAGUE"] project. Its aim was to improve the ecological status of the streams by increasing their morphological variability and habitat offer for aquatic organisms [13]. Data were obtained within the project about physicochemical and chemical parameters and about populations of benthic invertebrates including the presence of crayfish in seven larger streams in Prague.

This paper aims at providing information that Prague has lacked to present day: namely at presenting an evaluation of the ecological status of small watercourses by analogy to the WFD procedures $[14,15]$. At the same time, our aim has been to complement data about water quality from sites that are not monitored long-term. In this context, findings about the presence of crayfish have also been included since their protection is topical and closely linked to water quality.

\section{SITES AND METHODS}

\section{Sites}

A total of eight sites at seven watercourses in the capital city of Prague were selected for the research. Their location and basic characteristics are presented by a schematic map in Fig. 1 and Tab. 1.

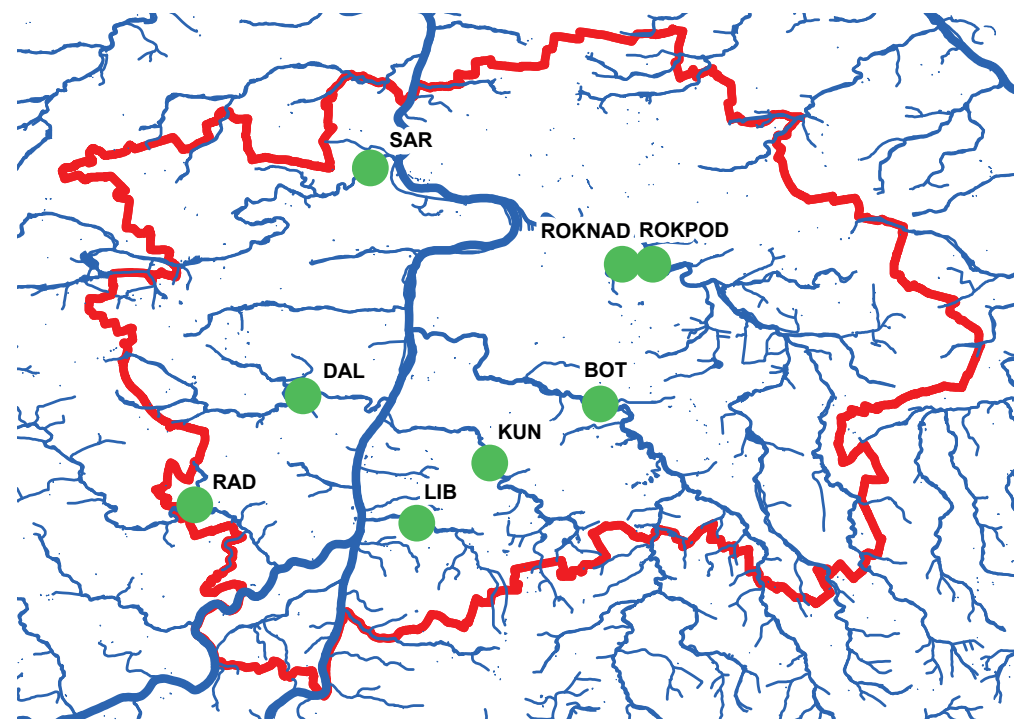

Fig. 1. Schematic depiction of small watercourse sites in the capital city of Prague

Selected sections of Botič, Radotínský, Libušský and Kunratický Streams may be characterised as unaltered and semi-natural watercourses. Forests and extensively used farming land with preserved river bank tree vegetation are in their vicinity.

Other four sites were selected in sections of watercourses where the stream bed has been restored in recent years. Rokytka above Hořejší Pond and Šárecký Stream in the Žežulka settlement are comprehensively restored watercourses. Dalejský Stream in the location of a former Klukovice outdoor swimming pool was irregularly broadened and now has a broad gravel bed. Rokytka below Hořejší Pond has an embedded high-capacity bed reinforced by boulders, which was, as far as the territory allowed, segmented by aggregate into sections with riffles. There are natural recreational areas in the vicinity of all the restored sections. A detailed description and rich picture documentation of the implemented restorations can be found on a website "Pražská príroda" ["Prague Nature"] [1]. Restoration modifications in these sites were completed two to four years before the sampling started. 


\begin{tabular}{|c|c|c|c|c|c|c|c|c|c|c|}
\hline 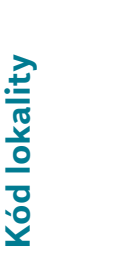 & $\begin{array}{l}y \\
0 \\
+1 \\
\frac{1}{0} \\
0\end{array}$ & 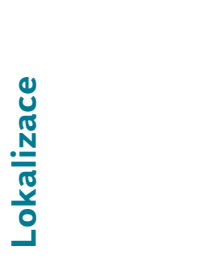 & 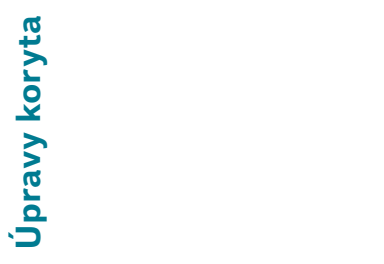 & 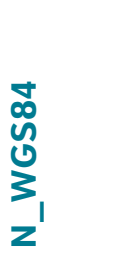 & 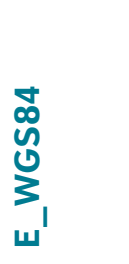 & 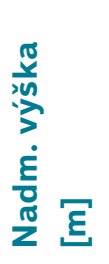 & 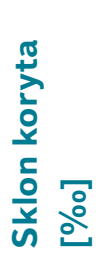 & 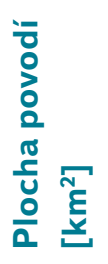 & 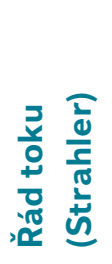 & 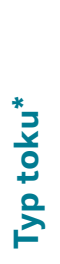 \\
\hline SAR & Šárecký p. & Žežulka & komplexní revitalizace (2013) & 50,11811 & 14,38052 & 190,7 & 8,7 & 59,0 & 3 & 1121 \\
\hline DAL & Dalejský p. & $\begin{array}{l}\text { pod ústím } \\
\text { Prokopského p. }\end{array}$ & komplexní revitalizace (2013) & 50,03953 & 14,36056 & 237,6 & 17,2 & 32,3 & 3 & 1221 \\
\hline RAD & Radotínský p. & $\begin{array}{l}\text { nad Mlýnským } \\
\text { p. (Zmrzlík) }\end{array}$ & přírodě blízké koryto & 49,99918 & 14,31270 & 255,4 & 7,8 & 50,2 & 3 & 1221 \\
\hline LIB & Libušský p. & $\begin{array}{l}\text { nad sportov- } \\
\text { ním areálem }\end{array}$ & přírodě blízké koryto & 50,00378 & 14,42761 & 219,0 & 15,2 & 12,1 & 3 & 1211 \\
\hline KUN & Kunratický p. & u areálu IKEM & přírodě blízké koryto & 50,02583 & 14,46204 & 230,8 & 7,7 & 22,4 & 3 & 1211 \\
\hline BOT & Botič & $\begin{array}{l}\text { pod jezem } \\
\text { Marcela }\end{array}$ & $\begin{array}{l}\text { prírodě blízké koryto/ } \\
\text { renaturace }\end{array}$ & 50,05022 & 14,51424 & 223,9 & 3,4 & 106,0 & 4 & 1212 \\
\hline ROKNAD & Rokytka & $\begin{array}{l}\text { nad Hořejším } \\
\text { rybníkem }\end{array}$ & komplexní revitalizace (2015) & 50,09876 & 14,51926 & 203,5 & 0,7 & 120,0 & 4 & 1212 \\
\hline ROKPOD & Rokytka & $\begin{array}{l}\text { pod Hořejším } \\
\text { rybníkem }\end{array}$ & částečná revitalizace (2014) & 50,09983 & 14,52972 & 199,8 & 4,5 & 120,6 & 4 & 1112 \\
\hline
\end{tabular}

*) dle vyhlášky č. 49/2011 Sb., o vymezení útvarů povrchových vod

Tab. 1. Location and basic characteristics of the sampling profiles

\begin{tabular}{|c|c|c|c|c|c|c|c|c|c|c|}
\hline $\begin{array}{l}\frac{0}{0} \\
0 \\
0 \\
\stackrel{0}{0} \\
\text { in }\end{array}$ & 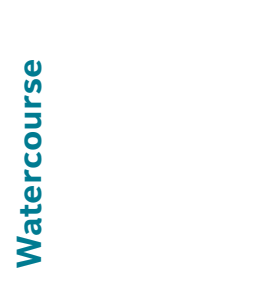 & בَّ & 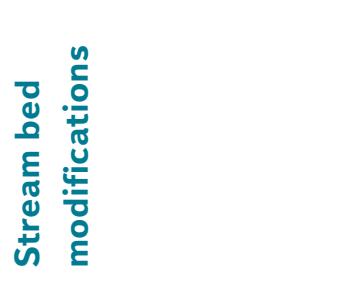 & $\begin{array}{l}\mathbb{D} \\
0 \\
0 \\
3 \\
z\end{array}$ & \begin{tabular}{l}
\multirow{0}{0}{} \\
ல \\
3 \\
\end{tabular} & 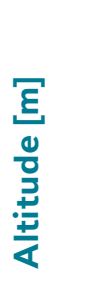 & 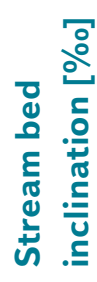 & 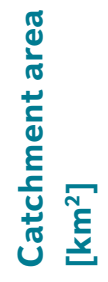 & 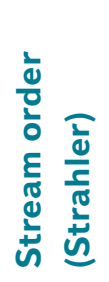 & $\stackrel{*}{*}$ \\
\hline SAR & Šárecký Stream & Žežulka & $\begin{array}{l}\text { Comprehensive } \\
\text { restoration (2013) }\end{array}$ & 50.11811 & 14.38052 & 190.7 & 8.7 & 59.0 & 3 & 1121 \\
\hline DAL & Dalejský Stream & $\begin{array}{l}\text { below the mouth of } \\
\text { Prokopský Stream }\end{array}$ & $\begin{array}{l}\text { Comprehensive } \\
\text { restoration (2013) }\end{array}$ & 50.03953 & 14.36056 & 237.6 & 17.2 & 32.3 & 3 & 1221 \\
\hline RAD & Radotínský Stream & $\begin{array}{l}\text { above Mlýnský } \\
\text { Stream (Zmrzlík) }\end{array}$ & Semi-natural stream bed & 49.99918 & 14.31270 & 255.4 & 7.8 & 50.2 & 3 & 1221 \\
\hline LIB & Libušský Stream & $\begin{array}{l}\text { above the sports } \\
\text { facility }\end{array}$ & Semi-natural stream bed & 50.00378 & 14.42761 & 219.0 & 15.2 & 12.1 & 3 & 1211 \\
\hline KUN & Kunratický Stream & in the IKEM premises & Semi-natural stream bed & 50.02583 & 14.46204 & 230.8 & 7.7 & 22.4 & 3 & 1211 \\
\hline BOT & Botič Stream & below Marcela Weir & $\begin{array}{l}\text { Semi-natural stream } \\
\text { bed/renaturation }\end{array}$ & 50.05022 & 14.51424 & 223.9 & 3.4 & 106.0 & 4 & 1212 \\
\hline ROKNAD & Rokytka & above Hořejší Pond & $\begin{array}{l}\text { Comprehensive } \\
\text { restoration (2015) }\end{array}$ & 50.09876 & 14.51926 & 203.5 & 0.7 & 120.0 & 4 & 1212 \\
\hline ROKPOD & Rokytka & below Hořejší Pond & Partial restoration (2014) & 50.09983 & 14.52972 & 199.8 & 4.5 & 120.6 & 4 & 1112 \\
\hline
\end{tabular}

*) Pursuant to Decree No. 49/2011 Coll., on the specification of surface water bodies 


\section{Odběr vzorků kvality vody}

Na vybraných lokalitách bylo od května 2017 započato vzorkování chemických ukazatelů $\left(\mathrm{CHSK}_{\mathrm{C}^{\prime}} \mathrm{BSK}_{5^{\prime}} \mathrm{NL}_{105^{\prime}}\right.$ formy dusíku a fosforu, obsah vápníku, hořčíku, síranů a chloridů) a měření fyzikálně-chemických ukazatelů kvality vody (teplota vody, elektrická konduktivita, obsah rozpuštěného kyslíku a pH). Monitoring byl prováděn v měsíčním intervalu po dobu jednoho roku, tedy do dubna 2018. Vzorky vody byly analyzovány ve Zkušební laboratoři technologií a složek životního prostředí VúVTGM. Měření fyzikálně-chemických parametrů bylo provedeno přímo na lokalitách měricím př́istrojem HACH HQ40d multi. Výjimkou byla lokalita na Libušském potoce, jež je téměř shodná s umístěním profilu dlouhodobého monitoringu kvality vody zajištóvaného HMP, a v rámci projektu nebylo efektivní vzorkovat a hodnotit stejný profil. Vzorky z tohoto odběrového místa byly proto odebrány jenom třikrát ve sledovaném období (5/2017, 10/2017, 4/2018). Na Rokytce byly vzorky vody odebírány pouze na profilu Rokytka nad Hořejším rybníkem, který je reprezentativní i pro níže položenou lokalitu Rokytka pod Hořejším rybníkem. Mezi oběma profily se na toku Rokytky nevyskytují žádné významné vlivy, Hořejší rybník je napájen bočním kanálem se zanedbatelným průtokem. Pro vyhodnocení chemických a fyzikálně-chemických parametrů byla použita Metodika hodnocení všeobecných fyzikálně-chemických složek ekologického stavu útvarů povrchových vod tekoucích [15]. Pro upřesnění je třeba poznamenat, že Libušský potok by uvedenou metodou neměl být hodnocen z důvodu nízkého počtu pouze tři odebraných vzorků. $V$ metodice hodnocení [15] je doporučeno použivat roční datovou sadu $s 12$ údaji. V prípadě, že je monitorovaných dat méně, neměl by jejich počet být nižší než 6 a data by měla reprezentovat celoroční cyklus sledování.

\section{Odběr vzorků makrozoobentosu}

Makrozoobentos byl vzorkován českou národní metodou Perla [16, 17] v období 2.-11. května 2017. Odběr probíhal s použitím ruční bentosové sítě s velikostí ok 0,5 mm po dobu tři minut proporcionálně z vyskytujících se habitatů. Všechny odebrané vzorky byly fixovány $v 4 \%$ formaldehydu a převezeny do laboratoře ke zpracování. Jednotlivé taxony vytříděné ze vzorků byly následně determinovány na co nejnižší možnou determinační úroveň. Při odběru vzorku byl zaznamenán základní hydromorfologický popis jednotlivých lokalit podle standardního odběrového protokolu [18]. Vyhodnocení společenstev makrozoobentosu bylo provedeno na základě metodiky pro hodnocení ekologického stavu povrchových vod tekoucích pomocí biologické složky makrozoobentos [14] s využitím modulu Riverchange, který je nadstavbou hodnotícího systému IS ARROW. $\checkmark$ rozporu s metodikou, jež pro celkové posouzení ekologického stavu požaduje hodnocení vzorku z jarní i z podzimní sezony, bylo provedeno pouze hodnocení jarního vzorku makrozoobentosu. Výsledné zařazení do tříd ekologického stavu je tedy nutné brát jen jako orientační.

\section{Astakologický průzkum}

Protože z území Prahy nebyly známy ucelené recentní informace o výskytu raků, jako součást výzkumu vodních bezobratlých proběhl též astakologický průzkum. Byl uskutečněn na začátku května 2017 na Šáreckém potoce, Říčanském potoce, Rokytce, Dalejském potoce a na Radotínském potoce. $V$ prípadě mělkých potoků byly jejich úseky prohledávány ručně $v$ místě potenciálních úkrytů. Vhodné úkryty raků jsou pod kameny, mrtvým dřevem, kořeny stromů a $\vee$ norách $\vee$ brezích. Ve zkoumaných úsecích bylo prohledáno pokud možno 100 jednotlivých úkrytů. Pokud se na vodním toku nacházely hlubší partie, které nešlo prohledávat ručně, byly zde položeny vrše s návnadou (játra), jež byly na lokalitách ponechány přes noc. Bližší popis použitých metod, charakteristik a rozsahu sledovaných úseků je uveden u každé lokality při popisu výsledků.

\section{Water quality sampling}

In May 2017, sampling of chemical indicators $\left(\mathrm{COD}_{\mathrm{Cr}^{\prime}} \mathrm{BOD}_{5^{\prime}} \mathrm{SS}_{105^{\prime}}\right.$, nitrogen and phosphorus forms, calcium, magnesium, sulphate and chloride content) started in selected sites together with the measurement of physicochemical water quality indicators (water temperature, electrical conductivity, dissolved oxygen content and $\mathrm{pH}$ ). Monitoring took place in monthly intervals for one year, i.e., until April 2018. Water samples were analysed in the TGM WRI Testing Laboratory of Technologies and Environment Components. Physicochemical parameters were measured directly in the sites by a measuring device $\mathrm{HACH}$ HQ40d multi. The Libušský Stream site was an exception because its location was almost identical to the location of the long-term water quality monitoring profile where measurement is done by the capital city of Prague and it was therefore not efficient to sample and evaluate the same profile. Samples from this sampling site were thus taken only three times over the monitoring period (5/2017, 10/2017 and 4/2018). Water samples from Rokytka were taken only in the Rokytka profile above Hořejší Pond, which is representative also for the lower site of Rokytka below Hořejší Pond. There are no important influences between both Rokytka profiles since Hořejší Pond is fed by a side channel with a negligible discharge. The Methodology for Evaluating General Physicochemical Quality Elements of the Ecological Status of Running Surface Water [15] was used to evaluate both chemical and physicochemical parameters. For the sake of clarity, it must be noted that Libušský Stream should not be evaluated by the above method due to the low number of only three taken samples. The evaluation methodology [15] recommends to use an annual dataset containing 12 data. If there are fewer monitored data, their number should not be lower than 6 and the data should represent the year-long monitoring cycle.

\section{Macroinvertebrates sampling}

Macroinvertebrates was sampled by the "Perla" Czech national method [16, 17] between $2^{\text {nd }}$ and $11^{\text {th }}$ May 2017. A manual benthos net with $0.5 \mathrm{~mm}$ mesh size was used for the sampling that was done for three minutes proportionally from the occurring habitats. All taken samples were fixed by $4 \%$ formaldehyde and taken to a laboratory for processing. Individual taxons separated from the samples were subsequently determined up to the lowest possible determination level. When samples were taken, a basic hydromorphological description of the individual sites was made pursuant to a standard sampling protocol [18]. Macroinvertebrates populations were evaluated on the basis of a methodology for evaluating the ecological status of running surface water by means of the macroinvertebrates biological quality elements [14] using the Riverchange module, which is an extension of the IS ARROW evaluation system. Contrary to the methodology, which requires an evaluation of samples from both the spring and autumn seasons for an overall assessment of the ecological status, only the spring macroinvertebrates sample was evaluated. The resulting classification into ecological status classes must therefore be regarded only as approximate.

\section{Astacological research}

Since no comprehensive recent information about the presence of crayfish in Prague was available, astacological research was carried out as part of the research of aquatic invertebrates. It took place at the beginning of May 2017 in Šárecký, Říčanský, Rokytka, Dalejský and Radotínský Streams. Potential hiding places in sections of shallow streams were searched manually. Suitable crayfish hiding places include places underneath stones, dead wood, tree roots and dens in riverbanks. A total of 100 individual hiding places were searched in the respective sections if possible. When the watercourses had deeper parts 


\section{VÝSLEDKY}

\section{Chemická a fyzikálně-chemická kvalita vody}

Souhrnné výsledky jednotlivých ukazatelů chemických a fyzikálně-chemických parametrů pro sledované lokality zobrazují grafy na obr. 2 a obr. 3.
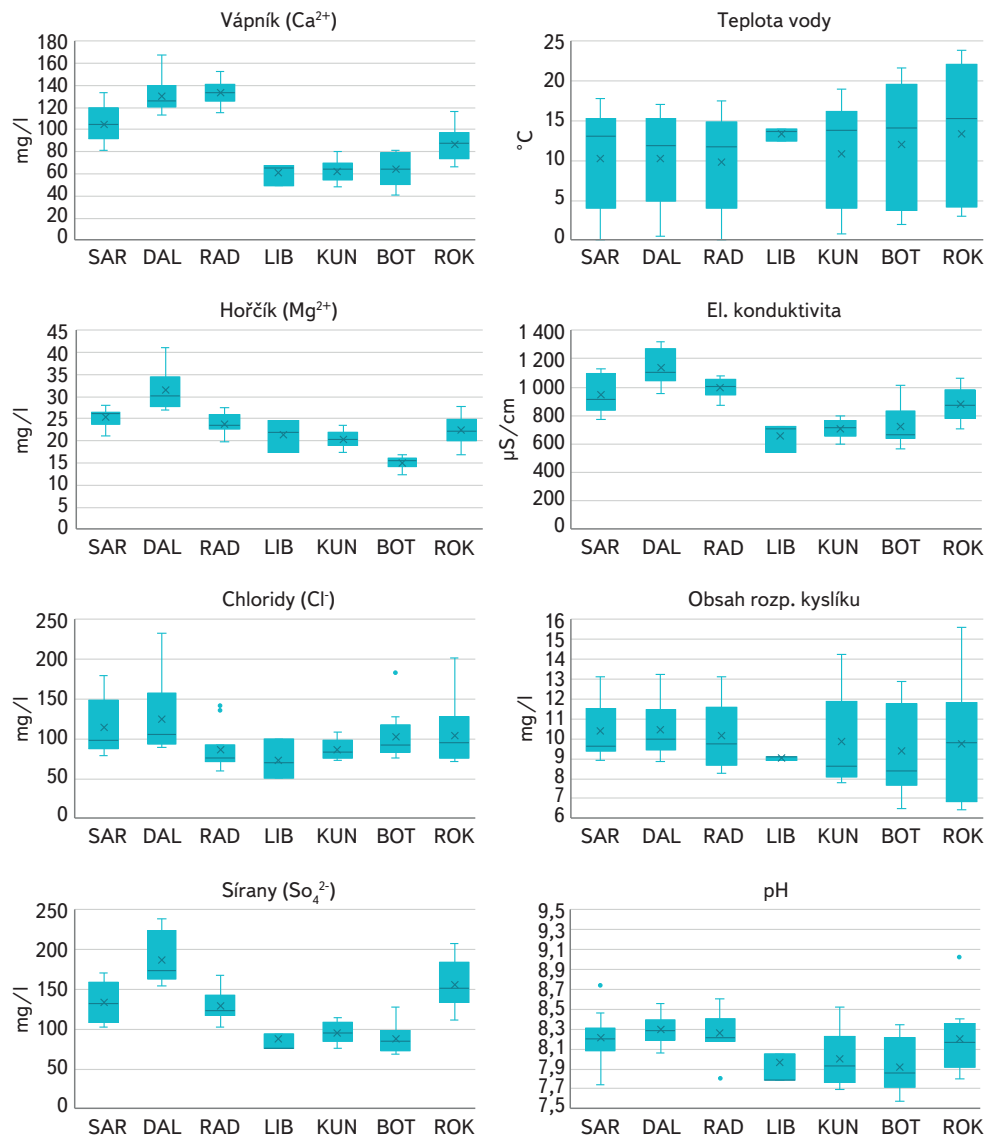

Obr. 2. Chemické a fyzikálně-chemické parametry kvality vody na vzorkovaných lokalitách v období 5/2017 až 4/2018. Kódy lokalit jsou popsány v tab. 1. Krabicový diagram znázorňuje medián, průměr (kř́žek), 1-3 kvartil (krabička), maxima a minima (vousy), odlehlé hodnoty jsou zobrazeny samostatnými kolečky

Dalejský a Radotínský potok, jejichž povodí leží v Barrandienu, se vyznačovaly vyšším obsahem vápenatých a hořečnatých iontů, což se projevuje též vyšším pH a elektrickou konduktivitou. V těchto ukazatelích má podobnou charakteristiku též Šárecký potok, který odvodñuje v horní části svého povodí zásadité jílovcové a prachovcové vrstvy.

Na Rokytce a Botiči presahovala letní maxima teplot vody hodnotu $20^{\circ} \mathrm{C}$, což bylo výrazně více než v ostatních potocích. Důvodem je pravděpodobně odtok ohřáté vody z epilimnia velkých nádrží, jež se nacházejí nad oběma sledovanými profily (Kyjský rybník na Rokytce, nádrž Hostivař na Botiči).

Znepokojivé jsou extrémně vysoké koncentrace celkového fosforu na Radotínském potoce s maximy kolem $2 \mathrm{mg} / \mathrm{l}$, jehož naprostá většina byla tvořena fosforečnanovým fosforem. Rovněž v koncentracích celkového, dusičnanového a amoniakálního dusíku hodnoty na Radotínském potoce několikanásobně prevyšovaly koncentrace zjištěné na ostatních potocích.

Standardizovaný pohled na hodnoty chemických a fyzikálně-chemických parametrů kvality vody poskytuje vyhodnocení do tríd ekologického stavu [15], které se používá pro hodnocení vodních útvarů v procesu plánování pro that could not be searched manually, coops were placed there with bait (liver) and left in the sites overnight. A more detailed description of applied methods, characteristics and scope of the monitored sections is made when the results are presented for each site.

\section{RESULTS}

\section{Chemical and physicochemical water quality}

Overall results of the individual indicators of chemical and physicochemical parameters regarding the monitored sites are presented by charts in Fig. 2 and Fig. 3.
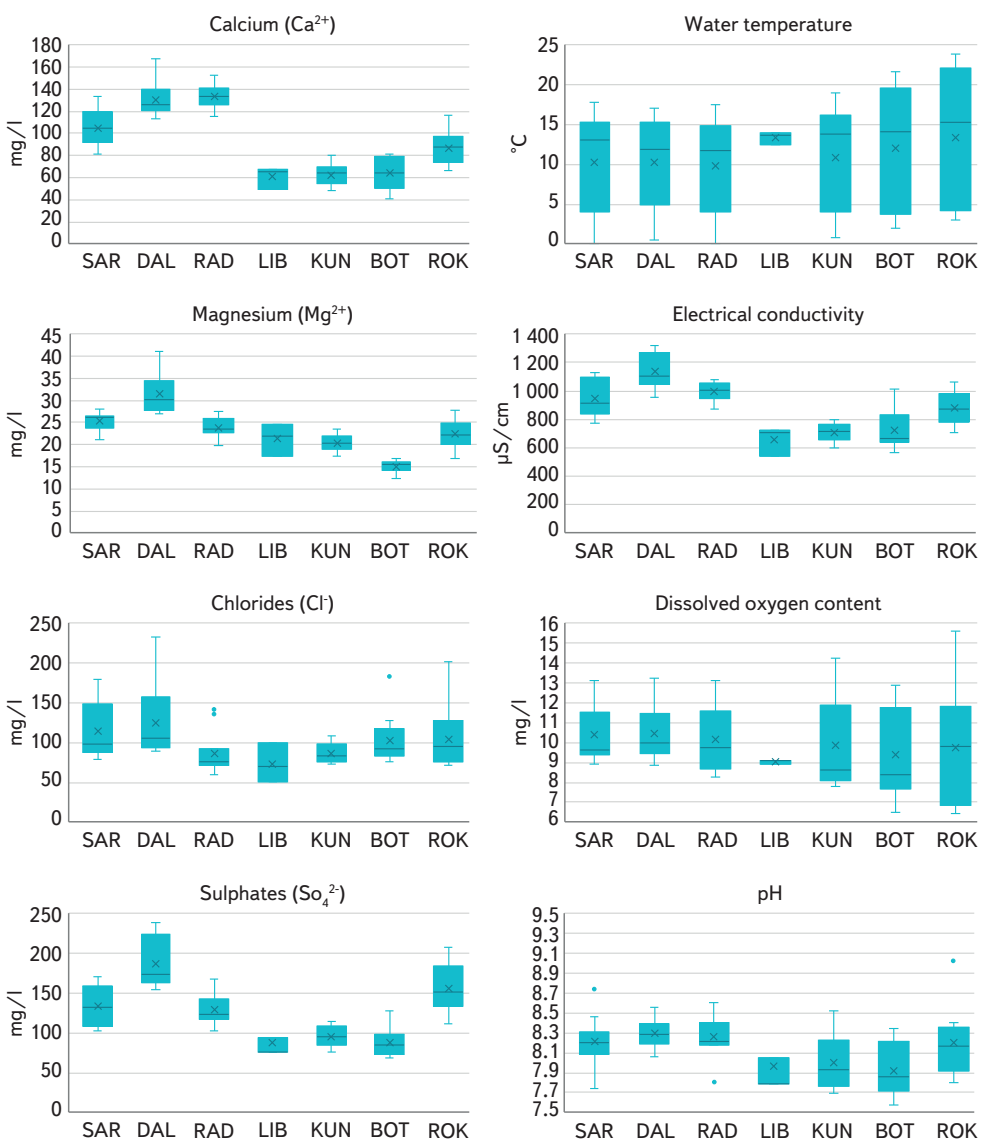

Fig. 2. Chemical and physicochemical water quality parameters in sampling sites between 5/2017 and 4/2018. Site codes are described in Tab. 1. The box diagram pre-

sents the median, average (cross), $1^{\text {st }}$ to $3^{\text {rd }}$ quartile (box) and maximums and minimums (whiskers); distant values are presented by separate circles.

Dalejský and Radotínský Streams, whose basin lies in the Barrandienne, had a higher calcium and magnesium ion content, which is also manifested by a higher $\mathrm{pH}$ and electrical conductivity. Šárecký Stream, which drains alkaline clay and siltstone layers in the upper part of its basin, has similar characteristics.

The maximum summer water temperatures of Rokytka and Botič exceeded $20^{\circ} \mathrm{C}$, which was significantly more than of the other streams. The reason for that is presumably the outflow of warmed water from the epilimnion of large water reservoirs that are located above both monitored profiles (Kyjský Pond at Rokytka and Hostivař Dam at Botič).

Extremely high concentrations of total phosphorus in Radotínský Stream with maximum values around $2 \mathrm{mg} / \mathrm{l}$ are disconcerting. A vast majority of the 

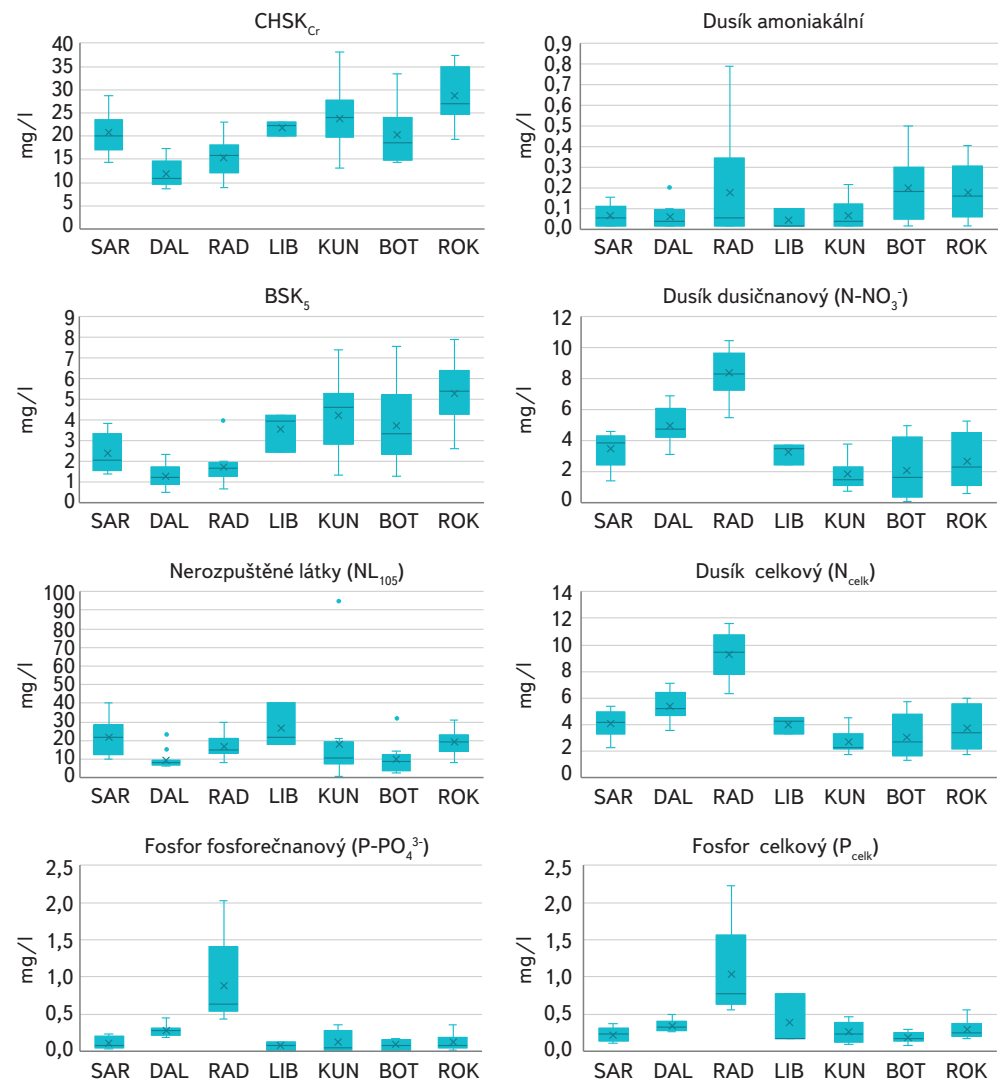

Obr. 3. Chemické a fyzikálně-chemické parametry kvality vody na vzorkovaných lokalitách v období 5/2017 až 4/2018. Kódy lokalit jsou popsány v tab. 1. Krabicový diagram znázorňuje medián, průměr (kř́žek), 1-3 kvartil (krabička), maxima a minima (vousy), odlehlé hodnoty jsou zobrazeny samostatnými kolečky

potřeby RSV [8]. Pro jednotlivé parametry jsou stanoveny limitní hodnoty, jež jsou specifické podle typu vodního toku. Typ vodního toku je určen podle Typologického členění vod v České republice $[19,20]$. Limity zařazují hodnoty do tři kategorií ekologického stavu: velmi dobrý (modrá), dobrý (zelená), střední a horší (žlutá). Pro výsledné zatřídění se používá nejhorší výsledek ze skupiny hodnocených parametrů. Velmi dobrý stav odpovídá podmínkám v neovlivněných vodních tocích. Dobrý stav je považován za mírnou odchylku od přirozeného stavu a je cílovým stavem v procesu zlepšování znečištěných vodních toků. Hodnocení všeobecných fyzikálně-chemických složek má jen funkci podpůrnou k biologickým složkám. Tam, kde monitoring biologických složek kvality chybí, se však pro hodnocení ekologického stavu vodních útvarů používá i samostatně.

Vyhodnocení fyzikálně-chemických parametrů sledovaných lokalit podle výše uvedené metody je zobrazeno $\vee$ tab. 2. V celkovém hodnocení byly všechny lokality zatříděny do středního a horšího stavu. Nejhorší výsledky přineslo vyhodnocení celkového a fosforečnanového fosforu, kde byly všechny lokality zařazeny do kategorie středního a horšího stavu. Z živinových parametrů na čtyřech potocích nevyhovoval obsah dusičnanového dusíku, a to zejména $v$ charakteristické hodnotě mediánu (RAD, DAL, SAR, LIB). Ve čtyrech prípadech byl překročen limit dobrého stavu pro BSK $5^{\prime}$ které je měřítkem obsahu dostupného uhlíku. $\vee$ pěti prípadech sledované potoky nesplnily limit pro teplotu vody, v prípadě Botiče a Rokytky dokonce jak v mediánových, tak i maximálních hodnotách. Poměrně lépe vycházelo hodnocení pro koncentrace amoniakálního dusíku, pH a nasycení kyslíkem.
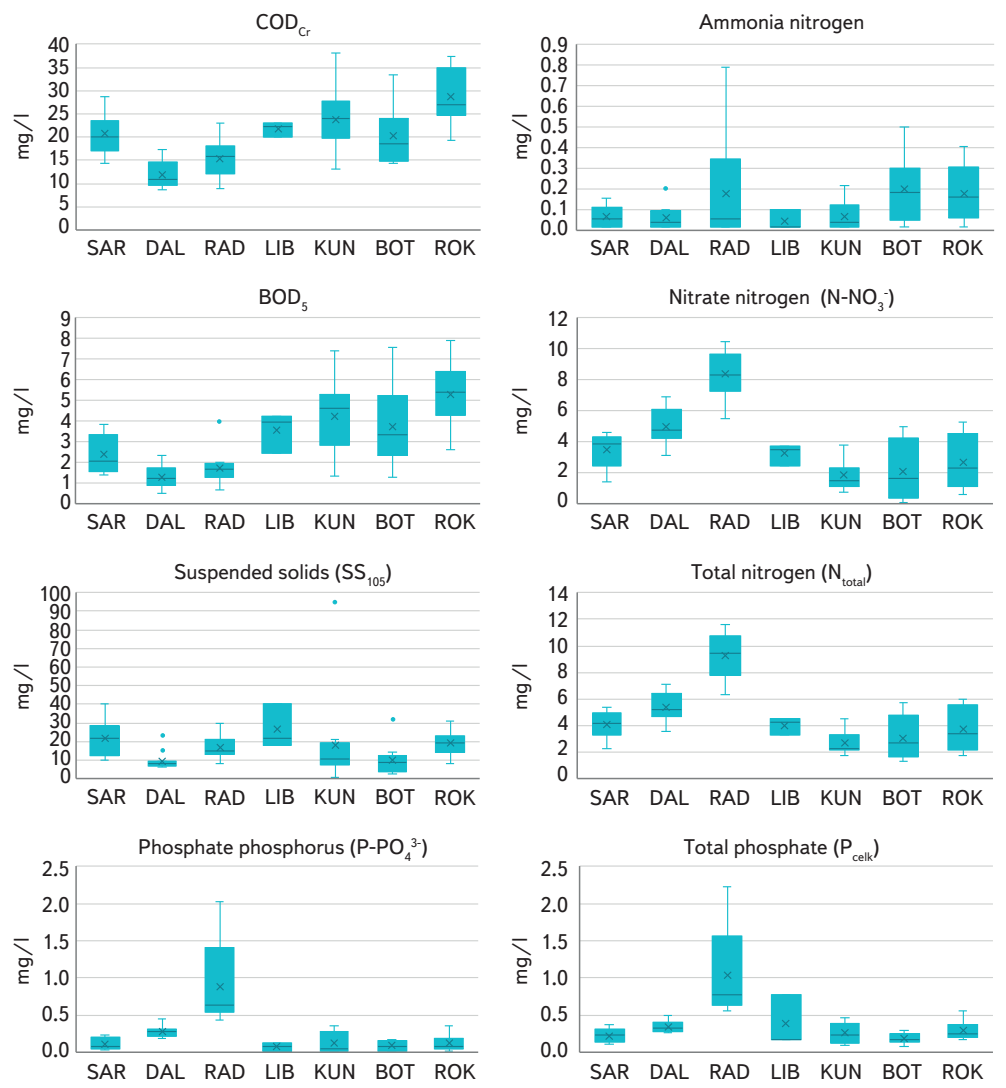

Fig. 3. Chemical and physicochemical water quality parameters in sampling sites between 5/2017 and 4/2018. Site codes are described in Tab. 1. The box diagram presents the median, average (cross), $1^{\text {st }}$ to $3^{\text {rd }}$ quartile (box) and maximums and minimums (whiskers); distant values are presented by separate circles.

concentrations were due to phosphate phosphorus. Concentrations of total, nitrate and ammonia nitrogen in Radotínský Stream also exceeded values established in the other streams severalfold.

An evaluation into ecological status classes [15] provides a standardised perspective on the values of chemical and physicochemical water quality parameters. For the purposes of the Water Framework Directive [8] it is used to evaluate water bodies in the planning process. Limit values are set for individual parameters, which are specific according to the type of water body. The type of water body is determined according to the typological classification of water in the Czech Republic $[19,20]$. Limits classify the values into three ecological status categories: high (blue), good (green), moderate and worse (yellow). The worst result from a group of evaluated parameters is used for the resulting classification. A high status corresponds to conditions in unaffected watercourses. Good status is regarded as a minor deviation from natural status and it is a target status in the process of improving polluted watercourses. An evaluation of general physicochemical quality elements plays only an auxiliary function with regard to biological quality elements. However, where monitoring of biological quality elements is absent, it is used for the evaluation of the ecological status of water bodies also independently.

An evaluation of physicochemical parameters of the monitored sites according to the above method is presented in Tab. 2. In the overall evaluation all the sites were classified as moderate and worse status. An evaluation of total and phosphate phosphorus yielded the worst results and all the sites were classified as moderate and worse status. As for nutrient parameters, the content of nitrate nitrogen was unsatisfactory in four streams, especially in the typical median value (RAD, DAL, SAR and LIB). The $\mathrm{BOD}_{5}$ limit of good status, which is 
Tab. 2. Vyhodnocení chemických a fyzikálně-chemických parametrů kvality vody podle standardni metodiky používané pro hodnocení vodnich útvarü [15].

Charakteristické hodnoty zjištěné na jednotlivých profilech jsou barevně odlišeny podle trúd ekologického stavu: modrá - velmi dobrý, zelená - dobrý, žlutá - střední a horší stav

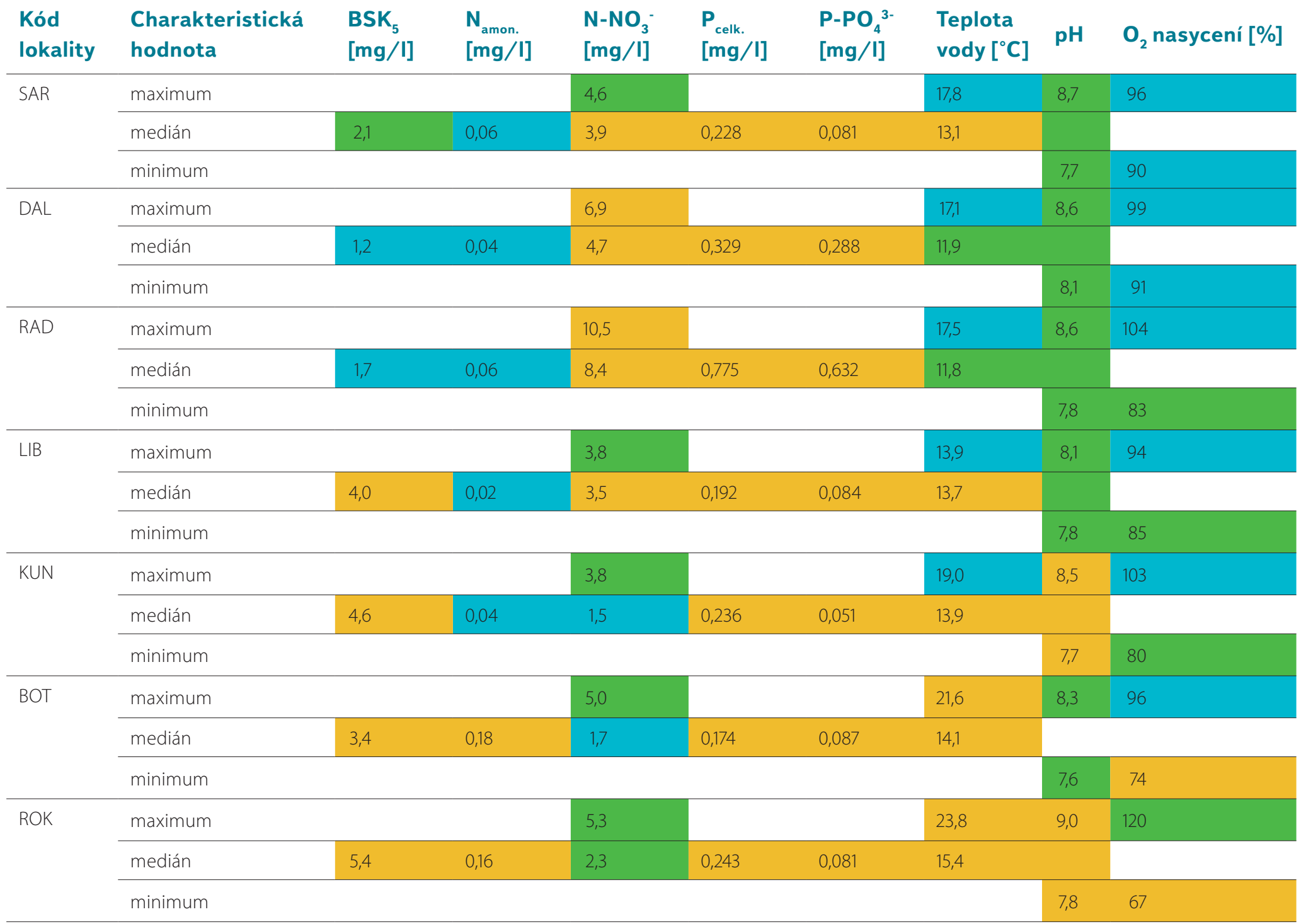

\section{Hydromorfologická charakteristika lokalit}

Dno většiny sledovaných vodních toků (SAR, DAL, RAD, KUN, LIB) tvořil převážně hrubý a jemný štěrk s malým podílem kamenů, prípadně balvanů (tab. 3). Balvany a kameny dominovaly $\vee$ zastoupení dnových substrátů na Botiči a pocházely pravděpodobně z rozpadlého břehového záhozu. Podobný podí velkého kameniva byl zaznamenán na Rokytce pod Hořejším rybníkem, kde šlo o materiál použitý pro stabilizaci a rozčlenění koryta při provedené „městské" revitalizaci zkapacitněného vodního toku. Úplně odlišné bylo dno komplexně revitalizované Rokytky nad Hořejším rybníkem, které bylo vytvořeno ve zcela nové meandrující trase v jílovité nivní půdě. Kompaktní jílovité dno zde doplňoval jen ojedinělý výskyt kamenů nebo štěrku. Na všech lokalitách převažovaly úseky proudící vody, tůně s klidnou vodou zaujímaly jen menší část plochy koryta. Na revitalizovaných úsecích Rokytky, Dalejského i Šáreckého potoka tůně dokonce zcela chyběly. Na jednotlivých lokalitách dosahovaly maximální hloubky v proudnici 20 až $100 \mathrm{~cm}$, střední hloubky se pohybovaly v rozsahu 10 až $40 \mathrm{~cm}$. Střední šírka toku v hladině byla odhadována v rozmezí 2-6 metrů. a measure for available carbon content, was exceeded in four cases. The water temperature limit was not met by five of the monitored streams; in the case of Botič and Rokytka even both in median and maximum values. An evaluation of the concentrations of ammonia nitrogen, $\mathrm{pH}$ and oxygen saturation yielded relatively better results.

\section{Hydromorphological characteristics of the sites}

The bottom of a majority of the monitored watercourses (SAR, DAL, RAD, KUN and LIB) was made of predominantly coarse and fine gravel with a small share of stones and boulders (Tab. 3). Boulders and stones dominated as a bottom substrate in Botič and likely came from a disintegrated bank reinforcement. A similarly big share of large aggregate was established in Rokytka below Hořejší Pond where this material had been used for stabilising and segmenting the stream bed during the implemented "urban" restoration that involved increasing the stream capacity. The bottom of the comprehensively restored Rokytka 
Tab. 2. Evaluation of chemical and physicochemical water quality parameters pursuant to a standard methodology used for evaluating watercourses [15].

Typical values established in the individual profiles are colour-coded according to ecological status classes: blue - high, green - good, yellow - moderate and worse status

\begin{tabular}{|c|c|c|c|c|c|c|c|c|c|}
\hline $\begin{array}{l}\text { Site } \\
\text { code }\end{array}$ & Typical value & $\begin{array}{l}\mathrm{BOD}_{5} \\
{[\mathrm{mg} / \mathrm{I}]}\end{array}$ & $\begin{array}{l}\mathrm{N}_{\text {ammonia }} \\
{[\mathrm{mg} / \mathrm{I}]}\end{array}$ & $\begin{array}{l}\mathrm{N}-\mathrm{NO}_{3}^{-} \\
{[\mathrm{mg} / \mathrm{I}]}\end{array}$ & $\begin{array}{l}P_{\text {total }} \\
{[\mathrm{mg} / \mathrm{I}]}\end{array}$ & $\begin{array}{l}\mathrm{P}-\mathrm{PO}_{4}{ }^{3-} \\
{[\mathrm{mg} / \mathrm{I}]}\end{array}$ & $\begin{array}{l}\text { Water } \\
\text { temperature }\left[{ }^{\circ} \mathrm{C}\right]\end{array}$ & $\mathrm{pH}$ & $\begin{array}{l}\mathrm{O}_{2} \text { saturation } \\
{[\%]}\end{array}$ \\
\hline \multirow[t]{3}{*}{ SAR } & maximum & & & 4.6 & & & 17.8 & 8.7 & 96 \\
\hline & median & 2.1 & 0.06 & 3.9 & 0.228 & 0.081 & 13.1 & & \\
\hline & minimum & & & & & & & 7.7 & 90 \\
\hline \multirow[t]{3}{*}{ DAL } & maximum & & & 6.9 & & & 17.1 & 8.6 & 99 \\
\hline & median & 1.2 & 0.04 & 4.7 & 0.329 & 0.288 & 11.9 & & \\
\hline & minimum & & & & & & & 8.1 & 91 \\
\hline \multirow[t]{3}{*}{ RAD } & maximum & & & 10.5 & & & 17.5 & 8.6 & 104 \\
\hline & median & 1.7 & 0.06 & 8.4 & 0.775 & 0.632 & 11.8 & & \\
\hline & minimum & & & & & & & 7.8 & 83 \\
\hline \multirow[t]{3}{*}{ LIB } & maximum & & & 3.8 & & & 13.9 & 8.1 & 94 \\
\hline & median & 4.0 & 0.02 & 3.5 & 0.192 & 0.084 & 13.7 & & \\
\hline & minimum & & & & & & & 7.8 & 85 \\
\hline \multirow[t]{3}{*}{ KUN } & maximum & & & 3.8 & & & 19.0 & 8.5 & 103 \\
\hline & median & 4.6 & 0.04 & 1.5 & 0.236 & 0.051 & 13.9 & & \\
\hline & minimum & & & & & & & 7.7 & 80 \\
\hline \multirow[t]{3}{*}{ BOT } & maximum & & & 5.0 & & & 21.6 & 8.3 & 96 \\
\hline & median & 3.4 & 0.18 & 1.7 & 0.174 & 0.087 & 14.1 & & \\
\hline & minimum & & & & & & & 7.6 & 74 \\
\hline \multirow[t]{3}{*}{ ROK } & maximum & & & 5.3 & & & 23.8 & 9.0 & 120 \\
\hline & median & 5.4 & 0.16 & 2.3 & 0.243 & 0.081 & 15.4 & & \\
\hline & minimum & & & & & & & 7.8 & 67 \\
\hline
\end{tabular}

\section{Makrozoobentos}

Hodnocení odebraných vzorků z jednotlivých lokalit shrnuje tab. 4. Nejvyšší početnost byla zaznamenána ve vzorku z Šáreckého potoka, jenž obsahoval přes 13000 jedinců. Naopak početnost na Rokytce nad Hořejším rybníkem a na Botiči byla přibližně třetinová. Na ostatních lokalitách se početnosti pohybovaly kolem 7-9 tisíc jedinců.

Ve vzorcích byly zjištěny běžně rozšírené taxony vodních bezobratlých. Druhově nejbohatší byl vzorek z Radotínského potoka s celkem 60 určenými taxony. Naopak nejchudší byl vzorek z Libušského potoka, kde se vyskytovalo jen 31 taxonů. Na ostatních lokalitách bylo určeno mezi 46-54 taxony. Počet zjištěných čeledí koreloval s počtem taxonů, nejvíce bylo zjištěno 33 čeledí na Radotínském potoce a nejméně 17 čeledí na Libušském potoce. Zjištěné početnosti a druhovou bohatost odráží Margalefưv index diverzity. Tento index je podílem počtu zjištěných taxonů a logaritmu celkového počtu jedinců ve vzorku. above Hořejší Pond was completely different and was created in a completely new meandering course in clay alluvial soil. A compact clay bottom was supplemented with only rarely present stones and gravel. Sections of running water were predominant in all sites whereas pools with calm water formed only a smaller area of the stream bed. Pools were even completely absent in the restored sections of Rokytka, Dalejský and Šárecký Streams. In the individual sites, their maximum depth in the streamline was 20 to $100 \mathrm{~cm}$ and mean depths ranged between 10 and $40 \mathrm{~cm}$. Mean width of the watercourses at water level was estimated at 2 to 6 metres.

\section{Macroinvertebrates}

The evaluation of samples taken from the individual sites is summarised in Tab. 4. The highest quantity was established in a sample from Šárecký Stream, 


\begin{tabular}{|c|c|c|c|c|c|c|c|c|c|c|c|c|c|c|c|}
\hline \multirow[b]{2}{*}{ 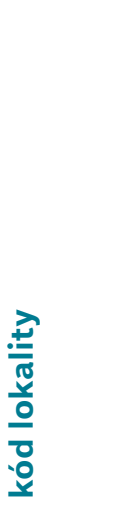 } & \multirow[b]{2}{*}{ 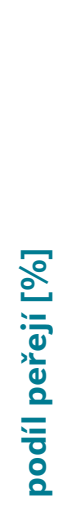 } & \multirow[b]{2}{*}{ 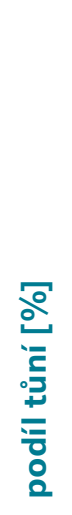 } & \multicolumn{7}{|c|}{ Pokryvnost dnových substrátů [\%] } & \multicolumn{3}{|c|}{ Hloubka toku [cm] } & \multicolumn{3}{|c|}{ Šířka toku v hladině $[\mathrm{m}]$} \\
\hline & & & 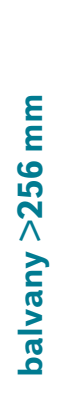 & 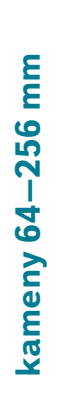 & 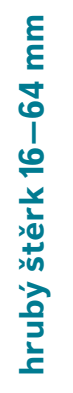 & 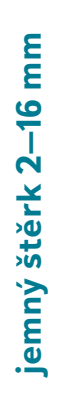 & $\begin{array}{l}E \\
E \\
N \\
\frac{1}{a} \\
0 \\
\frac{y}{d} \\
\frac{n}{2}\end{array}$ & 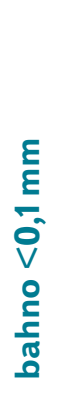 & . & $\cdot \frac{\dot{\Sigma}}{\varepsilon}$ & 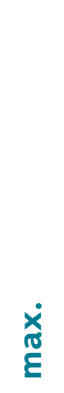 & 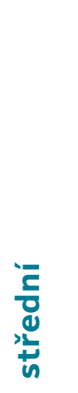 & $\cdot \frac{\dot{\Sigma}}{\varepsilon}$ & 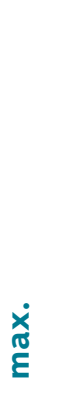 & 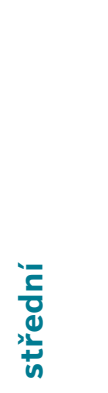 \\
\hline SAR & 50 & 0 & 5 & 5 & 50 & 30 & 10 & 0 & 0 & 10 & 25 & 15 & 2 & 4 & 3 \\
\hline DAL & 35 & 0 & 0 & 20 & 75 & 5 & 0 & 0 & 0 & 5 & 20 & 10 & 3 & 5,5 & 4 \\
\hline RAD & 50 & 10 & 0 & 5 & 50 & 30 & 10 & 5 & 0 & 10 & 60 & 20 & 1,5 & 4 & 3 \\
\hline LIB & 60 & 20 & 0 & 15 & 60 & 10 & 15 & 0 & 0 & 5 & 65 & 25 & 2 & 6 & 3 \\
\hline KUN & 30 & 30 & 5 & 15 & 25 & 45 & 5 & 5 & 0 & 5 & 70 & 25 & 2 & 4 & 2 \\
\hline BOT & 70 & 5 & 40 & 30 & 20 & 10 & 0 & 0 & 0 & 25 & 100 & 40 & 4 & 6 & 5 \\
\hline ROKNAD & 50 & 0 & 0 & 2 & 5 & 0 & 0 & 0 & 93 & 25 & 50 & 40 & 2,5 & 5 & 3,5 \\
\hline ROKPOD & 35 & 0 & 30 & 35 & 10 & 5 & 15 & 0 & 5 & 15 & 70 & 25 & 5 & 6 & 6 \\
\hline
\end{tabular}

Tab. 3. Basic hydromorphological characteristics of the monitored sites

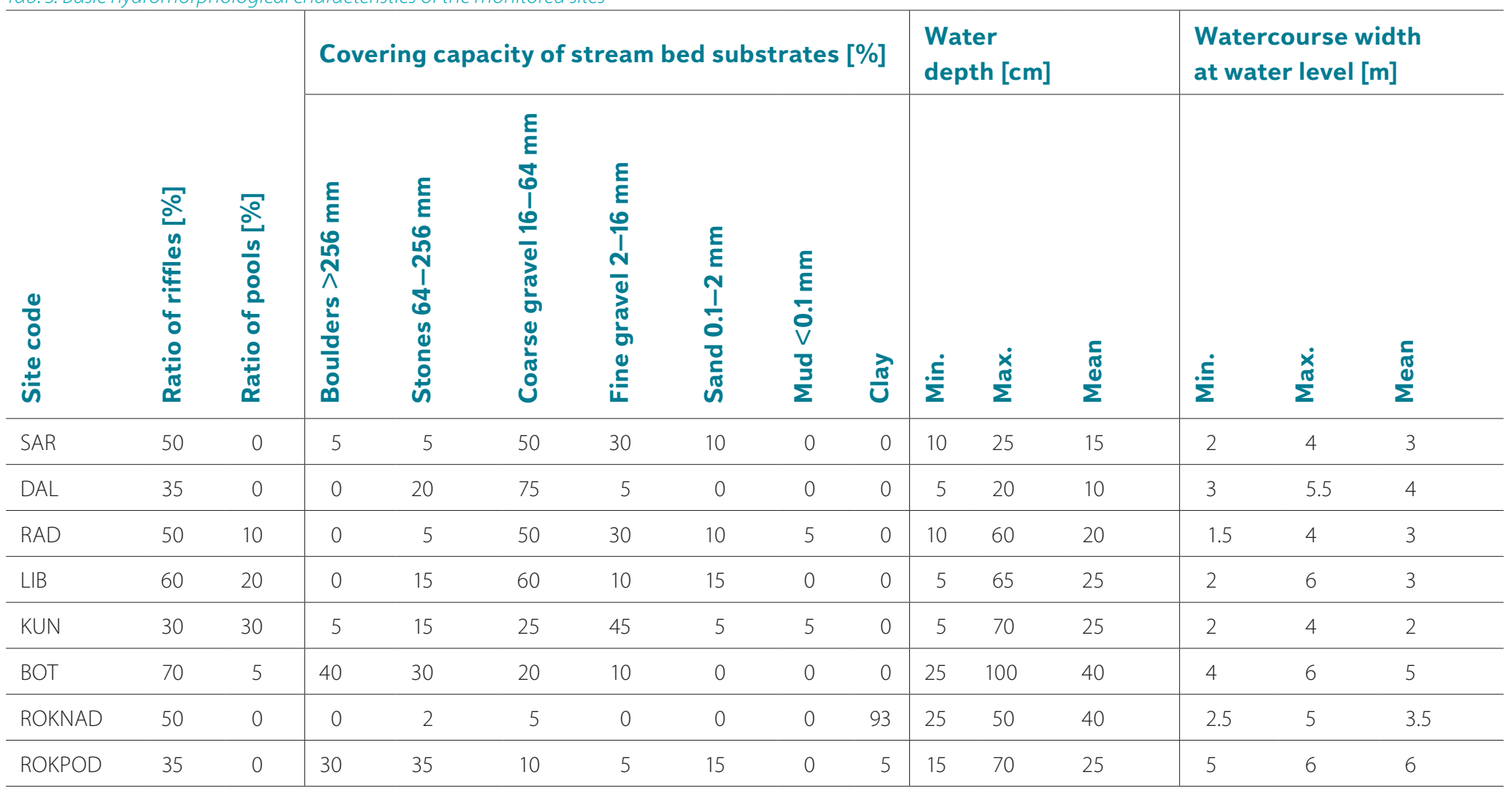




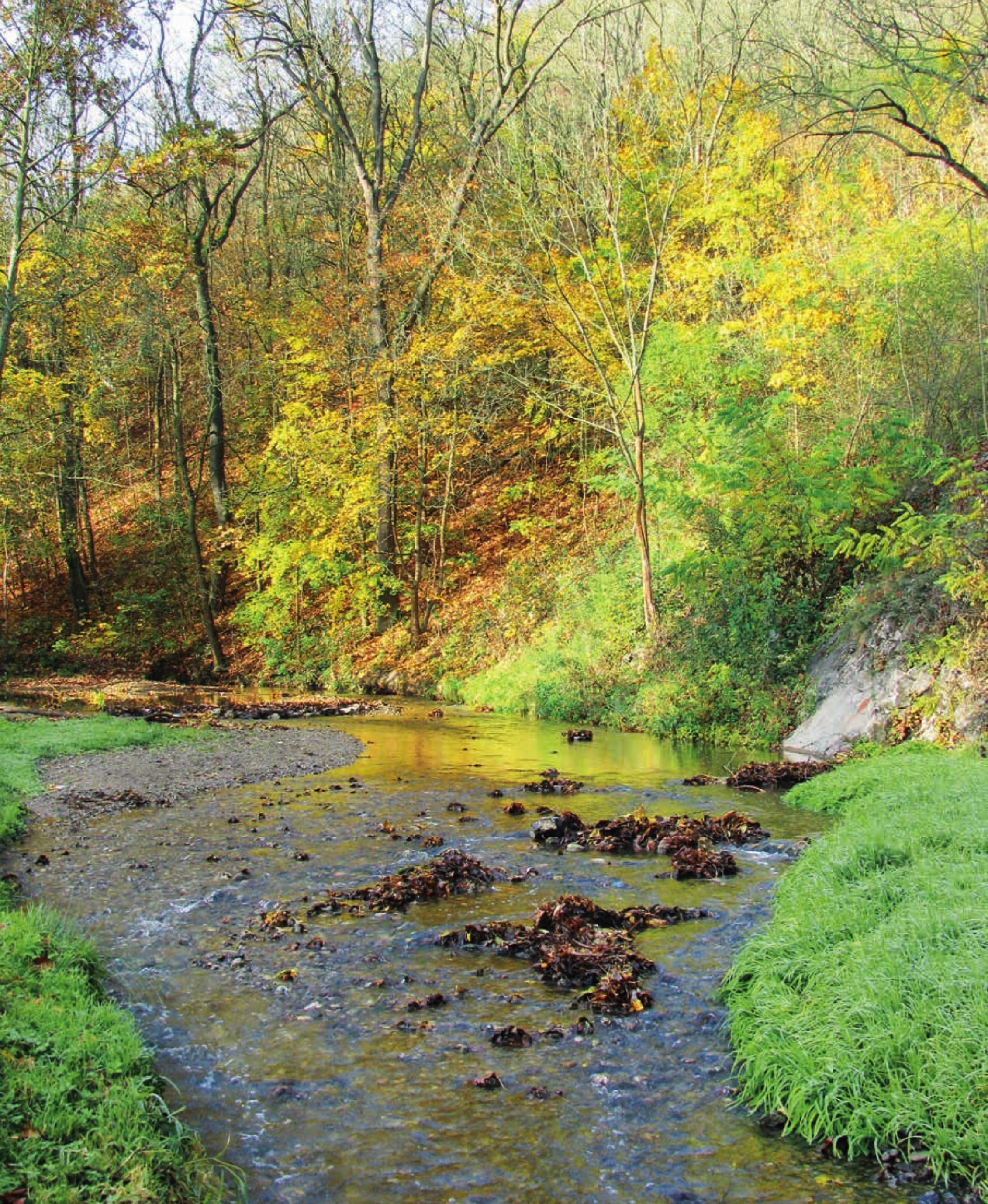


Vyšší hodnota indexu tedy značí vyšší diverzitu společenstva [14]. Nejvyšších hodnot dosahoval na Radotínském potoce a Rokytce nad Hořejším rybníkem, naopak nejnižší hodnota vychází pro společenstvo Libušského potoka.

Barevná část tab. 4 zobrazuje hodnoty EQR (ecological quality ratio) jednotlivých metrik společenstva makrozoobentosu. Ty nabývají hodnoty od 0 do 1 a s různou vahou (v závislosti na typu) vstupují do výpočtu výsledného multimetrického indexu makrozoobentosu. Jeho hodnota je rozdělena do pěti tříd ekologického stavu (velmi dobrý, dobrý, střední, poškozený, zničený). Pro přehlednost jsou barvami označujícími třídu ekologického stavu znázorněny i hodnoty EQR jednotlivých metrik.

Všechny sledované lokality dosahují v multimetrickém indexu pouze poškozeného nebo středního stavu. Šárecký potok, Rokytka pod Hořejším rybníkem, Radotínský a Libušský potok spadají na základě společenstva makrozoobentosu do středního ekologického stavu. Dalejský potok, Kunratický potok, Rokytka nad Hořejším rybníkem a Botič jsou zařazeny do poškozeného ekologického stavu. Souhrnně Ize říci, že hodnota EQR se na všech lokalitách pohybuje kolem hranice poškozeného a středního stavu $(0,4)$, přičemž žádná z lokalit se neblíži hranici žádoucího dobrého stavu (EQR $>0,6)$. Podle hodnot EQR Saprobního indexu je zřejmé, že všechny sledované toky trpí vysokou zátěží organickými látkami, což dokládá i nízká abundance EPT skupin makrozoobentosu (jepice, pošvatky a chrostíci).

Zajímavým výsledkem je horší ekologický stav lokality Rokytka nad Hořejším rybníkem než pod ním a než na Šáreckém potoce i přes to, že provedená revitalizace je ve srovnání s nimi nejvíce prírodě blízká.

\section{Astakologický průzkum}

Šárecký potok byl prozkoumán od Nebušického potoka po soutok s VItavou. Úseky byly nejdřive prohledávány ručně v místě potenciálních úkrytů. Přestože byl zaznamenán dostatek vhodných úkrytů, žádní raci nalezeni nebyli. V hlubších partiích koryta, které nebylo možné prohledávat ručně, byly položeny vrše s návnadou a ty byly na lokalitách ponechány přes noc. Ani metodou vrší však žádní raci nebyli nalezeni.

Průzkum Říčanského potoka byl prováděn pod obcí Dubeč od parku Panská zahrada po proudu směrem k Lítožnickým rybníkům. Ruční metodou hledání $\checkmark$ úkrytech nebyli v tomto úseku žádní raci nalezeni. Stejným způsobem byl proveden průzkum břehových partií rybníka $\vee$ Rohožníku v Dubči. Ani zde nebyli raci nalezeni. Průzkum byl ovšem prováděn jen v denní dobu, kdy pohyb raků mimo úkryt potlačuje bohatá rybí obsádka.

Astakologický průzkum na Rokytce byl proveden v okolí lávky přes Rokytku, $\checkmark$ dolní části Hořejšího rybníka. Při ručním průzkumu úkrytů nebyli nalezeni žádní raci. Úkryty zde ale nejsou pro raky př́liš vhodné. V úseku je dno sice kamenité, kameny jsou však často pevně usazené ve dně nebo volně ložené $v$ břehových partiích s jemným bahnitým sedimentem.

Radotínský potok je znám jako lokalita výskytu raka kamenáče (Austropotamobius torrentium), jenž je zařazen mezi prioritní druhy soustavy Natura 2000 a patří mezi kriticky ohrožené druhy podle prílohy III. vyhlášky č. 395/1992 Sb. [21]. Průzkum byl proveden 9. června 2017, prohledány byly úkryty na trvalé monitorovací ploše (Natura 2000) pod jezem u prítoku Zmrzlík. V tomto úseku nebyl žádný rak nalezen, proto průzkum pokračoval i výše nad jezem. Ani zde nebyl nalezen žádný jedinec raka. Při průzkumu byla voda v toku nepřirozeně černě zakalená a místy pokrytá pěnou. Průzkum byl proveden ještě na další trvalé monitorovací ploše nad obcí Choteč, rovněž bez nálezu. Dno Radotínského potoka tu bylo pokryté jemným černým sedimentem, který pokrýval všechny úkryty, včetně prázdných nor, jež v tomto úseku často sloužily rakům jako úkryty.

Průzkum Dalejského potoka se uskutečnil od Holyně až pod Řeporyje. Potok má $v$ tomto úseku charakter prírodního toku s velkým množstvím úkrytů pod kameny, mrtvým dřevem, pařezy a kořeny v břehových partiích. which contained over 13,000 specimens. On the contrary, Rokytka above Hořejší Pond and Botič only had approximately one third of that quantity. Quantities in the other sites ranged between 7 and 9,000 specimens.

Widespread taxons of aquatic invertebrates were established in the samples. A sample from Radotínský Stream was the richest in species, containing 60 taxons. On the contrary, the poorest sample was from Libušský Stream where only 31 taxons were present. Between 46 and 54 taxons were determined in the remaining sites. The number of established families correlated with the number of taxons: the highest number of families (33) was established in Radotínský Stream and the lowest (17) in Libušský Stream. The established abundance and richness in species are reflected by the Margalef diversity index. This index is a ratio of the number of established taxons and a logarithm of the overall number of specimens in a sample. The higher the index, the higher the diversity of a population [14]. This index reached its highest values in Radotínský Stream and Rokytka above Hořejší Pond, whilst the Libušský Stream population had the lowest value.

The colour part of Tab. 4 presents EQR (Ecological Quality Ratio) values of the individual metrics of the macroinvertebrates population. The values range between 0 and 1 and have different weights (depending on the type) in a calculation of the final multi-metric macroinvertebrates index. Its value is segmented into five ecological status classes (high, good, moderate, poor and bad). For the sake of clarity, the colours used for coding the ecological status classes are also used to present the EQR values of the individual metrics.

All the monitored sites reach only poor or moderate status in the multi-metric index. Based on the macroinvertebrates population, Šárecký Stream, Rokytka below Hořejší Pond, Radotínský and Libušský Streams have moderate ecological status. Dalejský Stream, Kunratický Stream, Rokytka above Hořejší Pond and Botič are classified as poor ecological status. Overall, it may be said that the EQR value in all sites oscillates around the threshold of poor and moderate status (0.4) and none of the sites are close to the threshold of the desirable good status (EQR > 0.6). According to the EQR values of the saprobic index, it is clear that all monitored watercourses suffer from a high organic substances load, which is also evidenced by the low abundance of EPT macroinvertebrates groups (Ephemerida, Plecoptera and Trichoptera).

A worse ecological status of the Rokytka site above Hořejší Pond compared to below it and compared to Šárecký Stream is an interesting finding. This is in spite of the fact that the restoration implemented there was the most semi-natural compared to the two latter sites.

\section{Astacological research}

Šárecký Stream was explored from Nebušický Stream up to the confluence with VItava River. Its sections were first searched manually in the potential hiding places. Even though enough suitable hiding places were found, no crayfish were discovered. In the deeper parts of the stream bed that could not be searched manually coops with bait were placed and left in the sites overnight. However, not even the coop method led to the discovery of crayfish.

Říčanský Stream was explored below the Dubeč municipality from the Panská zahrada Park downstream in the direction of Lítožnice Ponds. A manual search method discovered no crayfish in the hiding places in this section. River bank areas of Rohožník Pond in Dubeč were searched using the same method and no crayfish were found there either. The search was done only in the daytime when crayfish do not leave their hiding places because of the rich fish stock.

Astacological research in Rokytka Stream was done in the vicinity of a footbridge across the stream, in the lower part of Hořejši Pond. Manual search of hiding places did not lead to the discovery of any crayfish. However, hiding 
Hydromorfologický stav a rychlost proudění odpovídají podle zkušenosti stanovištím původních druhů raků. Žádní jedinci raků však v tomto úseku nalezeni nebyli. Průzkum byl proveden také na nádrži na Dalejském potoce na začátku obce Řeporyje. Zde byl nalezen jedinec raka bahenního (Astacus leptodactylus), který je zařazen mezi druhy ohrožené [21].

\section{DISKUZE}

\section{Chemické a fyzikálně-chemické ukazatele}

V síti státního monitoringu probíhá na území Prahy pravidelné sledování kvality vody na pěti profilech drobných vodních toků. Tři profily jsou situovány v ústí Rokytky (Libeň), Botiče (Nusle) a Radotínského potoka (Radotín). Zbývající dva profily leží na okraji Prahy - Na Rokytce v Běchovicích a na Botiči v Křeslicích. $\checkmark$ procesu plánování v oblasti vod podle RSV je pozornost věnována jen vodním tokům, které jsou vymezeny jako samostatné vodní útvary. Z drobných toků na území Prahy jsou vodním útvarem pouze Rokytka (DVL_0750) a Botič (DVL_0740). Přestože jsou v obou prípadech vymezeny od pramene po ústí do Vltavy, jejich reprezentativní profil, na němž probíhá hodnocení, je umístěn ve zmíněných profilech na okraji Prahy. V hodnocení obou vodních útvarů se tedy neprojevuje vliv samotné pražské aglomerace, velkých nádrží, jako je Počernický a Kyjský rybník na Rokytce a nádrž Hostivař na Botiči, nebo některých prítoků. Podle vyhodnocení stavu vodních útvarů publikovaných státním podnikem Povodí Vltavy [12] spadá výsledné hodnocení obou vodních útvarů do stupně "střední a horší stav", tedy stejné kategorie, která vychází pro Rokytku a Botič na námi sledovaných profilech. Výčet ukazatelů nesplňujících limit pro dobrý stav je však mírně odlišný.

Na Botiči mezi Křeslicemi a námi sledovaným profilem klesá významně medián koncentrací dusičnanového dusíku (až na úroveň velmi dobrého stavu) a $v$ menší míre též medián celkového fosforu (ovšem nikoli mimo limit středního a horšího stavu). V obou prípadech jde nepochybně o vliv retence a denitrifikace dusičnanů a retence fosforu v hostivařské nádrži, která však naopak zhoršuje teplotní poměry vodního toku ohřiváním v letních měsících.

Na Rokytce se pokles v obsahu živin mezi profilem v Běchovicích a námi sledovaným profilem nad Hořejším rybníkem neprojevuje. Dưvodem může být přetrvávající živinové zatí̌ení Počernického a Kyjského rybníka, ale také nesrovnatelnost obou profilů. Měření na Rokytce v Běchovicích probíhají ještě nad přítokem znečištěných potoků Říčanského a Běchovického.

Ostatní sledované pražské potoky nevyhovovaly limitu dobrého stavu všeobecných fyzikálně-chemických složek nejčastěji v ukazateli fosforečnanového a celkového fosforu a také dusičnanového dusíku. Všechny tyto potoky odvodňují hustě osídlené oblasti městské a prríměstské zástavby a do většiny z nich jsou zaústěny vyčištěné odpadní vody z místních čistíren odpadních vod. Nejvyšší mediánové hodnoty celkového i fosforečnanového fosforu byly zjištěny na Radotínském a Dalejském potoce. Tyto dva potoky však zároveň vykazovaly nízké hodnoty BSK $_{5}$ na úrovni velmi dobrého stavu. Tento zdánlivý paradox Ize snad vysvětlit rychlým odbouráváním snadno dostupného organického uhlíku v proudící a poměrně dobře prokysličené vodě obou potoků, zatímco fosforečnan je v zastíněném korytě poměrně pomalu asimilován do biomasy zelených řas.

Při porovnání s vodními útvary dílčího povodí Dolní Vltavy [12] dojdeme k závěru, že pražské potoky se $v$ charakteristice obohacení živinami zásadně neliší od ostatních vodních toků. Ze 79 vodních útvarů tekoucích vod nevyhověl požadavkům všeobecných fyzikálně-chemických složek ekologického stavu ani jediný. A právě nevyhovující stav v ukazatelích živinového zatížení fosforem a dusíkem patřil mezi nejčastější důvody. places there are not very suitable for crayfish. Although the stream bottom in the section is stony, the stones are often solidly embedded in the river bottom or freely placed in the bank parts with fine mud sediment.

Radotínský Stream is known as a site where stone crayfish (Austropotamobius torrentium) is present, which belongs among Natura 2000 priority species and among critically endangered species pursuant to Annex III to Decree No. 395/1992 Coll. [21]. The search took place on 9/6/2017 and hiding places in the permanent monitoring area (Natura 2000) were searched below a weir near the Zmrzlík tributary. Since no crayfish were found in that section, the search continued above the weir. However, no crayfish specimen was found there either. During the search, water in the stream had an unnatural blackish colour and was covered by foam in some places. The search was then carried out in another permanent monitoring area above the Choteč municipality and no specimen was found either. The bottom of Radotínský Stream was covered with fine black sediment there, which covered all hiding places including empty dens that often used to serve as hiding places for crayfish in this section.

Dalejský Stream was searched from Holyně up to Řeporyje. The stream has the character of a natural watercourse in this section with a large number of hiding places under stones, dead wood and tree stumps and roots in bank areas. According to experience, the hydromorphological status and flow speed correspond to habitats of native crayfish species. However, no crayfish specimens were discovered in this section. A water reservoir at Dalejský Stream at the beginning of the Řeporyje municipality was also searched. A specimen of Narrow-clawed crayfish (Astacus leptodactylus) that is an endangered species was found there.

\section{DISCUSSION}

\section{Chemical and physicochemical indicators}

As part of state monitoring grids, water quality in Prague is regularly monitored in five profiles of small watercourses. Three profiles are situated in the mouth of Rokytka (Libeň), Botič (Nusle) and Radotínský Stream (Radotín). The two remaining profiles are located on the outskirts of Prague, in Rokytka in Běchovice and Botič in Kreslice. Pursuant to the WFD, attention in the water planning process is paid only to watercourses that are defined as water bodies. Out of the small watercourses in Prague, only Rokytka (DVL_0750) and Botič (DVL_0740) are water bodies. Even though they are in both cases defined from the spring up to when they empty into Vltava River, their representative profile where evaluation takes place is located in the above profiles on the outskirts of Prague. Evaluation of both water bodies is therefore affected neither by the actual impact of the Prague agglomeration, large water reservoirs such as Počernický and Kyjský Ponds at Rokytka and Hostivař Reservoir at Botič nor by any of their tributaries. According to an evaluation of water bodies published by the state-owned enterprise Povodí VItavy [12], the resulting evaluation of both water bodies is classified as "moderate and worse status", i.e., the same categories that resulted for Rokytka and Botič in the profiles that we had monitored. However, the list of indicators that do not meet a limit for good status is slightly different.

The median of ammonia nitrogen concentration drops significantly in Botič between Kreslice and the profile we monitored (up to the high status level) and to a smaller degree the median of total phosphorus drops too (however, not beyond the moderate and worse status limit). Undoubtedly, in both cases this is an effect of nitrates retention and denitrification and phosphorus retention in Hostivař Reservoir, which deteriorates temperature conditions of the watercourse by warming up in summer months. 
Podrobný monitoring fyzikálně-chemických a chemických parametrů kvality vody provádí na drobných vodních tocích na svém území hlavní město Praha [1]. Řada profilů umožňuje srovnání s výsledky naší studie, jejich souhrnné vyhodnocení je však provedeno do tříd jakosti vod podle normy ČSN 757221 [2].

Na profilu č. 18A Radotínského potoka u Rutenického mlýna jsou približně od roku 2015 měěeny zvýšené koncentrace BSK ${ }_{5}$ CHSK $_{\mathrm{C}^{\prime}}$ dusičnanového dusíku i celkového fosforu. Tyto hodnoty jsou rádově v souladu $s$ našimi výsledky a dokládají, že mimořádné zatížení živinami započalo na Radotínském potoce již asi dva roky před naším průzkumem. Nelze však souhlasit s komentárem k hodnocení, který vzrůstající koncentrace celkového fosforu přisuzuje komunálním odpadním vodám z trativodů ze staré zástavby v obcích. Naše výsledky a jednorázová pozorování jednoznačně nasvědčují havarijnímu stavu provozu čistíren odpadních vod. Velmi pravděpodobně jde o vliv silného komunálního znečištění v pramenné části Radotínského potoka, kde přetížené čistírny odpadních vod nestačí tempu nové zástavby.

Vlivem, jenž mohl zůstat nepozorován ve výsledcích laboratorních analýz, je deštové odlehčení. Běžným monitoringem ho nelze zachytit. Objem znečištění, který se při odlehčení do vodních toků dostane, může být podstatným příspěvkem k eutrofizaci [22].

\section{Makrozoobentos}

Hodnocení makrozoobentosu multimetrickým indexem podle metod RSV přináši řadu otázek. Radotínský potok byl hodnocen do středního ekologického

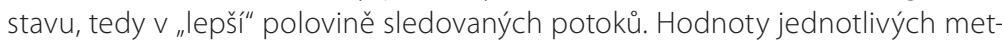
rik v př́padě Radotínského potoka silně kolísají od EQR Saprobního indexu na úrovni zničeného stavu až po hodnoty B indexu a Margalefovy diverzity, které odpovídají stavu dobrému. Připomeňme též extrémně vysoké koncentrace celkového fosforu i vysoké koncentrace forem dusíku ukazující na značné zatížení toku živinami. Tyto živinové parametry mají prímou vazbu na autotrofní biologické složky kvality (fytobentos, makrofyta), makrozoobentos ovlivňují nepřímo přes živinový koloběh v toku [23]. Sledovaný úsek Radotínského potoka je hydromorfologicky i složením substrátu dna prírodě blízký. Společenstvo bentických bezobratlých zde dosahuje nejvyšší diverzity ze sledovaných toků, což je v souladu se skutečností, že makrozoobentos je významně ovlivňován právě habitatovou diverzitou vodního toku. Organické znečištění vody v toku promítající se do zcela nevyhovujícího EQR Saprobního indexu pak patrně limituje společenstvo k dosažení pouze středního ekologického stavu a pravděpodobně je hlavní překážkou pro dosažení dobrého ekologického stavu.

Radotínský potok je pouze nejnápadnějším príkladem rozdílu ve vyhodnocení EQR jednotlivých metrik, který můžeme pozorovat i u některých dalších lokalit (Šárecký potok, Rokytka pod Hořejším rybníkem, Kunratický potok, Botič). Saprobní index je metrika založená na citlivosti vybraných taxonů k zatížení vod lehce rozložitelnou organickou hmotou. Metrika primárně indikuje organické znečištění, ale pozitivně koreluje také s intenzitou eutrofizace, zemědělským využitím říční nivy i povodí a některými prvky hydromorfologické degradace [14]. B index je počitán predikčním modelem. Ten modeluje teoretickou skladbu společenstev makrozoobentosu na konkrétních lokalitách na základě sedmi hodnot proměnných prostředí (vzdálenost od pramene, nadmořská výška, zeměpisná šířka, zeměpisná délka, spád toku, plocha povodí, rád toku). Index B je pak získán následným srovnáním společenstva predikovaného a na hodnocené lokalitě zjištěného [14]. Rozdíly v EQR Saprobního a B indexu tedy odrážejí skutečnost, že toky jsou hydromorfologicky i složením substrátu dna prírodě blízké nebo revitalizované do prírodě blízkého hydromorfologického stavu, ale organické znečistění vody v toku je nevyhovující.

Pravidelné vyhodnocení společenstva vodních bezobratlých do tříd ekologického stavu je pro pražské potoky prováděno pouze na Rokytce a Botiči, jež jsou vodními útvary ve smyslu RSV [8]. Jak již bylo popsáno výše, vzorkování je
No decrease in nutrients is apparent in Rokytka between the profile in Běchovice and the profile we monitored above Hořejší Pond. A reason for this may be a persistent nutrient load of Počernický and Kyjský Ponds as well as the incomparability of both profiles. Rokytka measurements in Běchovice take place before the polluted Říčanský and Běchovický tributaries.

The other monitored Prague streams did not meet the good status limit for general physicochemical quality elements most often in the phosphate phosphorus and total phosphorus indicators as well as in nitrate nitrogen. All these streams drain densely populated areas of urban and suburban settlements and treated waste water from local waste water treatments stations is led there. The highest median values of total and phosphate phosphorus were established in Radotínský and Dalejský Streams. However, at the same time these two streams had very low $\mathrm{BOD}_{5}$ values, corresponding to a high status. This seeming paradox can easily be explained by fast degradation of easily available organic carbon in running and fairly well-oxygenated water in both streams whereas phosphate in the shady stream bed gets assimilated into the green algae biomass rather slowly.

When making a comparison with water bodies of the sub-basin of the Lower VItava [12], a conclusion may be drawn that Prague streams do not significantly differ from other watercourses as regards the characteristics of nutrient enrichment. Out of 79 running water bodies, not a single one met the requirements of general physicochemical quality elements of the ecological status. The most common reasons for that included unsatisfactory status of phosphorus and nitrogen nutrient load.

The capital city of Prague carries out a detailed monitoring of physicochemical and chemical water quality parameters of small watercourses in its territory [1]. Numerous profiles enable a comparison with the results of our paper but their overall evaluation is done into water quality classes pursuant to the ČSN Technical Standard 757221 [2].

Approximately since 2015 , increased concentrations of $\mathrm{BOD}_{5^{\prime}} \mathrm{COD}_{\mathrm{Cr}^{\prime}}$ ammonia nitrogen and total phosphorus have been measured in profile No. 18A in Radotínský Stream near Rutenický Mill. These values are roughly in line with our results and show that the extraordinary nutrient load of Radotínský Stream began already approximately two years before our research. However, we cannot agree with a comment attached to the evaluation that the increasing concentrations of total phosphorus are attributed to municipal waste water from the porous piping system from the old buildings in the municipality. Our results and one-time observations clearly indicate that the waste water treatment stations that are in operation are in serious disrepair. There is a highly likely impact of strong municipal pollution in the source part of Radotínský Stream where overloaded waste water treatment stations cannot keep step with the new development.

The impact posed by reducing torrential rain load may have gone unnoticed in the laboratory analysis results. This impact cannot be captured by standard monitoring. However, the volume of pollution that gets to watercourses in that case may be a significant contribution to eutrophication [22].

\section{Macroinvertebrates}

An evaluation of macroinvertebrates by a multi-metric index in accordance with the WFD methods brings a number of questions. Radotínský Stream was evaluated as moderate ecological status, i.e., the "better" half of monitored streams. Values of individual metrics in Radotínský Stream strongly oscillate between the EQR of the saprobic index at the level of bad status up to $B$ index values and the Margalef diversity index corresponding to good status. The extremely high concentrations of total phosphorus and high concentrations of nitrogen forms that indicate a significant nutrient load of the watercourse should also be noted. These nutrient parameters have a direct link to autotrophic biological quality elements (phytobenthos and macrophytes) and have an indirect 
prováděno státním podnikem Povodí Vltavy v reprezentativních profilech na okraji Prahy. Návrh aktuálního plánu dílčího povodí pro 3. plánovací cyklus [12] uvádí hodnocení makrozoobentosu na Rokytce ve 4. třídě ekologického stavu (poškozený stav). Botič je ve stejném dokumentu hodnocen ve třídě 3 (střední ekologický stav). Stejně jsou oba vodní útvary hodnoceny i v předchozím plánovacím cyklu. Rozdíly $v$ hodnocení oproti našim výsledkưm jsou dány pravděpodobně odlišnými vlivy na vodní tok i mikrohabitatovými charakteristikami vzorkovaných profilů. Z nádrže Hostivař a Kyjského rybníka odtéká v letních měsících voda obohacená o fytoplankton řas a sinic, který negativně ovlivňuje zastoupení potravních skupin makrozoobentosu [23]. Citlivost metody hodnocení na mikrohabitatové podmínky vodního toku Ize dokumentovat na rozdílném výsledku na profilech Rokytky pod a nad Hořejším rybníkem (tab. 4). Proudný úsek pod Hořejším rybníkem s kamenitým substrátem dna byl hodnocen o třídu lépe než odběrový úsek nad Hořejším rybníkem. Paradoxem je, že tato lokalita byla komplexně revitalizována do široce meandrujícího koryta. Vzorkování tu však proběhlo teprve dva roky po dokončení revitalizačních úprav. Za hlavní důvod zatřídění lokality do poškozeného stavu však považujeme uniformní podmínky revitalizovaného koryta, které bylo vyhloubeno v kompaktním jílu. I po dvou letech tady nevznikly štěrkové náplavy ani nedošlo k prohloubení tůní. Zde je na místě uvést, že pracovníci Magistrátu hlavního města Prahy zareagovali rychle na naše předběžná zjištění a nechali revitalizované koryto obohatit o štěrk a říční dřevo.

Ostatní údaje o hodnocení drobných toků v Praze do ekologického stavu podle makrozoobentosu jsou spiše výjimečné. Starší práce dokumentují nedosažení dobrého stavu na profilech Botiče na základě Saprobního a ASPT indexu [3, 4]. V roce 2017 prováděla vzorkování makrozoobentosu na Botiči Lískovcová [6]. Hodnocení na základě jednotlivých metrik na profilech pod nádrží Hostivař kolísalo mezi středním a zničeným stavem.

Hodnocení menších pražských potoků, jež nejsou vodním útvarem, dosud nebylo metodami analogickými k hodnocení vodních útvarů provedeno. $\checkmark$ tomto spočívá prínos naší studie, která kromě Rokytky a Botiče hodnotí ještě dalších pět potoků třetího řádu dle Strahlera. Výsledné hodnocení do tříd středního a poškozeného stavu není překvapivé. Pravděpodobně ho nevylepšilo ani odchýlení od standardní metodiky, kdy jsme hodnotili jen jarní vzorky, jež bývají bohatší. Na vodní toky v městském prostředí působí řada nepříznivých vlivů. $V$ této práci jsme se věnovali zejména kvalitě vody a částečně hydromorfologickým charakteristikám. V městských tocích se však také negativně projevuje hydraulický stres [5], dramatické zhoršení kvality vody vlivem deštového odlehčení kanalizačních systémů [22] nebo vliv starých ekologických zátěží [24]. Pro hrubé srovnání stavu drobných toků v Praze může posloužit výsledek hodnocení podle makrozoobentosu pro vodní útvary v dílčím povodí Dolní Vltavy [12]. Pouze polovina vodních útvarů dosáhla ve složce ekologické kvality makrozoobentos dobrého stavu. Druhá polovina vodních útvarů je hodnocena do třídy středního nebo poškozeného stavu.

\section{Astakologický průzkum}

Při hodnocení výskytu raků je třeba důsledně odlišovat mezi původními a nepůvodními druhy. Ve Vltavě na území Prahy se již několik desetiletí vyskytuje populace nepưvodního raka pruhovaného (Faxonius limosus), jenž se do ČR rozšíril proti proudu Labe. Tento invazní druh většinou nevystupuje do drobných vodních toků, může sem však být aktivně přenesen lidmi. Toto riziko platí zejména pro rybníky a vodní nádrže. Příkladem byl rybník V Rohožníku na Říčanském potoce $\vee$ Dubči. Zdejší silná populace raka pruhovaného byla $\checkmark$ roce 2014 potlačena vypuštěním a odbahněním rybníka. Náš průzkum byl motivován snahou zjistit, zda byl zásah úspěšný. Existovala totiž domněnka, že při vypouštění rybníka mohlo do Říčanského potoka velké množství jedinců uniknout. Průzkum jejich výskyt nepotvrdil ani ve vodním toku, ani v nově impact on macroinvertebrates via the nutrient cycle in the watercourse [23] The monitored section of Radotínský Stream is semi-natural from both the hydromorphological perspective and composition of the stream bed substrate. There the population of benthic invertebrates reaches the highest diversity out of the monitored watercourses, which is in line with the fact that macroinvertebrates is significantly affected by the habitat diversity of a watercourse. Organic water pollution in the watercourse, reflected in the fully unsatisfactory EQR of the saprobic index, presumably prevents the population from reaching a better than moderate ecological status and is likely to be the main barrier in reaching good ecological status.

Radotínský Stream is the most striking example of a difference in the evaluation of the EQR of individual metrics, which can be observed in other sites too (Šárecký Stream, Rokytka below Hořejší Pond, Kunratický Stream and Botič). Saprobic index is a metric based on the sensitivity of selected taxons to water load by easily degradable organic matter. The metric primarily indicates organic pollution but it also positively correlates with eutrophication intensity, farming use of the alluvial plain and basin as well as several elements of hydromorphological degradation [14]. The B index is calculated by a prediction model. It models the theoretical composition of macroinvertebrates populations in specific sites based on seven values of environment variables (distance from the source, altitude, latitude, longitude, inclination of the watercourse, catchment area and stream order). The index is the result of a subsequent comparison of predicted and actually established population in the evaluated site [14]. Differences in the EQR of saprobic and B indices therefore reflect the fact that from the hydromorphological perspective and composition of the stream bed substrate, the respective watercourses are semi-natural or restored into a semi-natural hydromorphological status but organic water pollution of the watercourse is unsatisfactory.

As regards Prague streams, regular evaluation of the population of aquatic invertebrates into ecological status classes is done only for Rokytka and Botič, which are water bodies within the meaning of the Water Framework Directive [8]. As described above, sampling is carried out by the state-owned enterprise Povodí Vltavy in representative profiles on the outskirts of Prague. The current Draft Catchment Area Plan for the $3^{\text {rd }}$ planning cycle [12] evaluates macroinvertebrates in Rokytka as Class 4 ecological status (poor status). Botič is classified as Class 3 (moderate ecological status) in the document. Both water bodies were evaluated in the same way also in the previous planning cycle. The differences compared to our results are presumably due to different impacts on the watercourses and microhabitat characteristics of the sampling profiles. In the summer months, water flowing away from Hostivař Reservoir and Kyjský Pond is enriched with the phytoplankton of algae and cyanobacteria, which negatively affects representation of the feeding groups of macroinvertebrates [23]. The sensitivity of the evaluation method regarding microhabitat conditions of watercourses may be documented on the different result in the profiles of Rokytka below and above Hořejší Pond (Tab. 4). The flow section below Hořejší Pond with stream bed substrate made of aggregate was evaluated by a class better than the sampling section above Hořejši Pond. It is a paradox that the latter site was comprehensively restored into a broadly meandering stream bed. However, sampling took place there only two years after the completion of restoration modifications. What we consider to be the main reason for classifying the site as having poor status is the uniform conditions of the of the restored stream bed, which had been dug in compact clay. Even after two years, neither gravel alluvia have formed there nor have the pools deepened. It should be noted in this context that the staff of the Prague City Hall quickly responded to our preliminary findings and had the stream bed enriched with gravel and river wood.

Other data about the ecological status evaluation of small watercourses in Prague according to macroinvertebrates are rather exceptional. Older papers document the failure to reach good status in Botič profiles on the basis of 


\begin{tabular}{|c|c|c|c|c|c|c|c|c|c|c|c|c|c|c|c|}
\hline 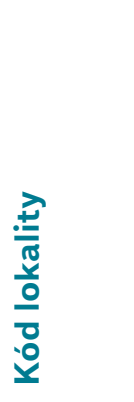 & 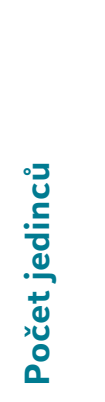 & 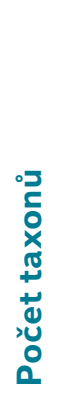 & 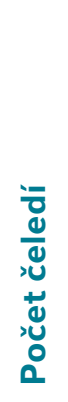 & 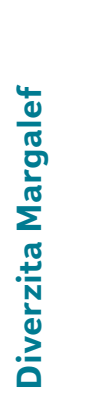 & 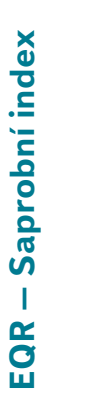 & 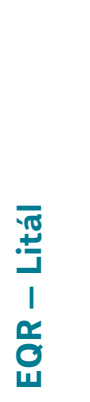 & 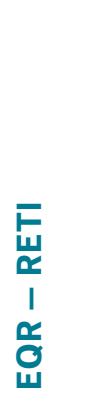 & 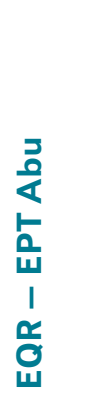 & 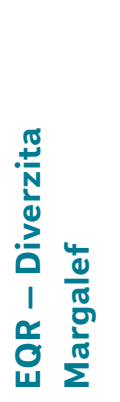 & 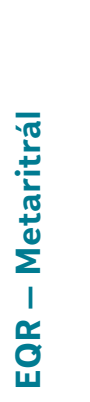 & 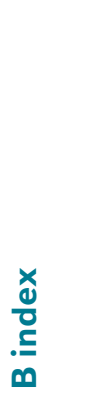 & 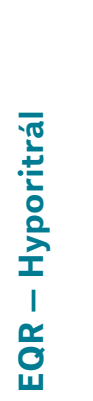 & 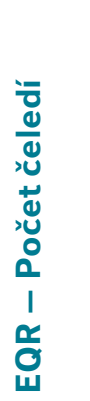 & 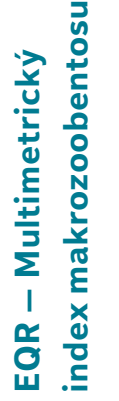 & 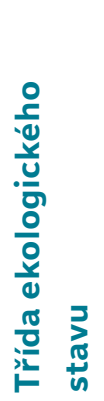 \\
\hline SAR & 13036 & 54 & 29 & 4,75 & 0,35 & 0,45 & 0,54 & 0,36 & 0,54 & 0,45 & 0,68 & & & 0,49 & 3 \\
\hline DAL & 9362 & 47 & 23 & 4,59 & 0,34 & 0,39 & 0,41 & 0,19 & 0,52 & 0,40 & 0,40 & & & 0,38 & 4 \\
\hline RAD & 9392 & 60 & 33 & 5,90 & 0,07 & 0,34 & 0,40 & 0,42 & 0,69 & 0,51 & 0,64 & & & 0,45 & 3 \\
\hline LIB & 7280 & 31 & 17 & 3,37 & 0,43 & 0,49 & 0,46 & 0,35 & 0,37 & 0,45 & 0,45 & & & 0,43 & 3 \\
\hline KUN & 9080 & 46 & 23 & 4,61 & 0,17 & 0,29 & 0,37 & 0,36 & 0,53 & 0,39 & 0,50 & & & 0,38 & 4 \\
\hline ВОТ & 5064 & 46 & 24 & 4,81 & 0,15 & 0,43 & 0,31 & 0,26 & 0,52 & 0,34 & 0,43 & & & 0,34 & 4 \\
\hline ROKNAD & 3902 & 49 & 24 & 5,56 & 0,39 & 0,33 & 0,28 & 0,32 & 0,61 & 0,28 & 0,30 & & & 0,34 & 4 \\
\hline ROKPOD & 8432 & 51 & 24 & 4,87 & 0,14 & 0,41 & 0,32 & 0,26 & & & 0,61 & 0,86 & 0,73 & 0,49 & 3 \\
\hline
\end{tabular}

Tab. 4. Overall evaluation of macroinvertebrates populations. The colours mark the division of the EQR into ecological status classes (high - blue, good - green, moderate - yellow, poor-orange, bad-red). A more detailed description of the metrics and calculation of the multi-metric index is presented in a methodology by Opatrilová et al. [14]

\begin{tabular}{|c|c|c|c|c|c|c|c|c|c|c|c|c|c|c|c|}
\hline 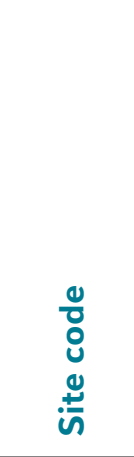 & 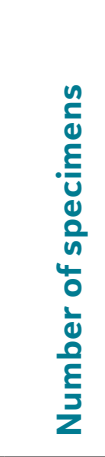 & 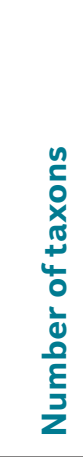 & 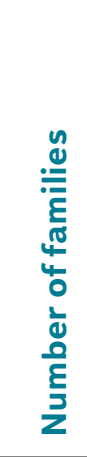 & 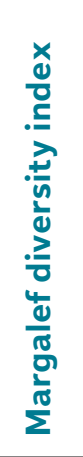 & 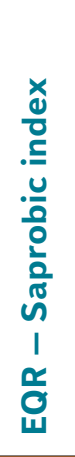 & 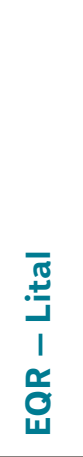 & 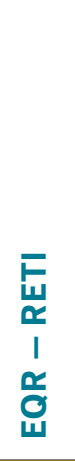 & 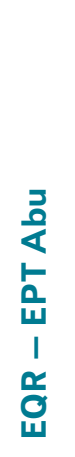 & 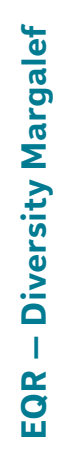 & 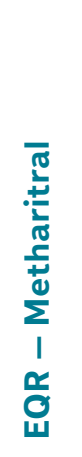 & 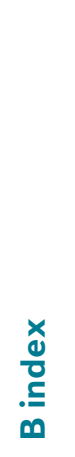 & 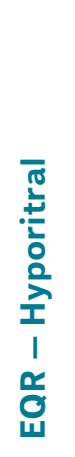 & 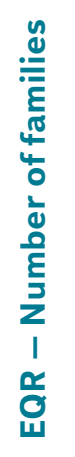 & 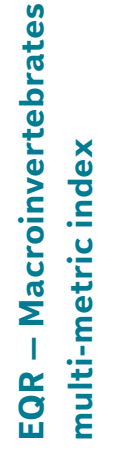 & 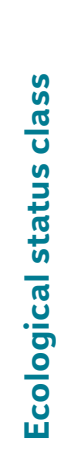 \\
\hline SAR & 13036 & 54 & 29 & 4.75 & 0.35 & 0.45 & 0.54 & 0.36 & 0.54 & 0.45 & 0.68 & & & 0.49 & 3 \\
\hline DAL & 9362 & 47 & 23 & 4.59 & 0.34 & 0.39 & 0.41 & 0.19 & 0.52 & 0.40 & 0.40 & & & 0.38 & 4 \\
\hline RAD & 9392 & 60 & 33 & 5.90 & 0.07 & 0.34 & 0.40 & 0.42 & 0.69 & 0.51 & 0.64 & & & 0.45 & 3 \\
\hline LIB & 7280 & 31 & 17 & 3.37 & 0.43 & 0.49 & 0.46 & 0.35 & 0.37 & 0.45 & 0.45 & & & 0.43 & 3 \\
\hline KUN & 9080 & 46 & 23 & 4.61 & 0.17 & 0.29 & 0.37 & 0.36 & 0.53 & 0.39 & 0.50 & & & 0.38 & 4 \\
\hline BOT & 5064 & 46 & 24 & 4.81 & 0.15 & 0.43 & 0.31 & 0.26 & 0.52 & 0.34 & 0.43 & & & 0.34 & 4 \\
\hline ROKNAD & 3902 & 49 & 24 & 5.56 & 0.39 & 0.33 & 0.28 & 0.32 & 0.61 & 0.28 & 0.30 & & & 0.34 & 4 \\
\hline ROKPOD & 8432 & 51 & 24 & 4.87 & 0.14 & 0.41 & 0.32 & 0.26 & & & 0.61 & 0.86 & 0.73 & 0.49 & 3 \\
\hline
\end{tabular}


napuštěném rybníku. Úsek potoka pod rybníkem V Rohožníku patři k rychle proudícím, jež nejsou k životu raků vhodné. Říčanský potok je velmi znečištěný komunálními odpadními vodami [1], takže pravděpodobně nevyhovuje ani invaznímu raku pruhovanému, který je méně citlivý ke znečištění než naši původní raci [25]. Ačkoli v době průzkumu raci v úseku nebyli nalezeni, v pozdější době byl pomocí mobilní aplikace „Raci v ČR" potvrzen výskyt raka pruhovaného rybáři v Kyjském rybníce.

Podezření na výskyt nepůvodního raka pruhovaného existovalo i na Rokytce. U Podvinného mlýna v Praze-Libni bylo v nedávné minulosti nalezeno několik jedinců raka pruhovaného [J. Patoka, osobní sdělení]. Náš průzkum v Rokytce na hranici Hloubětína a Vysočan naštěstí výskyt raka pruhovaného nepotvrdil.

Při průzkumu na Šáreckém potoce byla zvažována možnost výskytu původního evropského raka bahenního (Astacus leptodactylus). Jeden exemplár tohoto druhu byl nalezen v lednu 2015 v oblasti Zlatnice [J. Svobodová, nepublikováno]. Šlo o neobvyklý nález raka v zimním období mimo úkryt, což naznačuje, že nebyl v dobré kondici. Nejspíše to byl jedinec pocházející z některého rybníka, snad z nejbliže se nacházejícího rybníka u Dubového mlýna.

Nález raka bahenního v Dalejském potoce na horním okraji obce Řeporyje je potěšující, ale nikoli překvapivý. Lokalita se nachází v blízkosti bývalého skanzenu Řepora, z jehož rybníčků jsou nálezy raka bahenního známé [26]. Většímu rozšírení níže po proudu ale pravděpodobně brání komunální znečištění Dalejského potoka pod Řeporyjemi.

Asi nejvýznamnějším negativním zjištěním astakologického průzkumu je zánik populace raka kamenáče (Austropotamobius torrentium) na Radotínském potoce. Rak kamenáč se v minulosti dlouhodobě vyskytoval v úseku asi jeden kilometr nad obcí Choteč až po Radotín, tedy asi na pěti kilometrech Radotínského potoka [26]. Nejlepší situace na toku byla v roce 2010, kdy byla abundance i přes 60 raků na úseku. Časem se abundance začala snižovat, např. v roce 2014 byla jen 13 raků/100 vhodných úkrytů [26], ale populace byla ještě stále stabilní.

Jak je popsáno ve výsledcích chemických rozborů, povodí Radotínského potoka je silně zatiženo komunálními odpadními vodami. Z náhodných zjištění i prohlídek stavu vodního toku nad sledovanou lokalitou vyplývá, že úroveň jejich čištění je velmi nízká až havarijní. Náhodně zachycený vzorek vody z Radotínského potoka v Tachlovicích (asi 7 km nad sledovaným profilem) dne 14. zárí 2017 dokládá epizodické stavy neslučitelné se životem většiny vodních organismů (obsah rozpuštěného kyslíku 2 mg/l, amoniakální dusík 8,15mg/l, BSK $_{5} 47$ mg/I) [P. Kožený, nepublikováno].

Zhoršenou kvalitou vody $\vee$ Radotínském potoce se zabývali i pracovníci státního podniku Povodí Vltavy. V roce 2017 byla v potoce pod Tachlovicemi opakovaně v intervalu asi 14 dní zjištěna černě zakalená voda [J. Válek, osobní sdělení]. Zdrojem byla pravděpodobně špatně fungující čistírna odpadních vod v pramenné oblasti, nepodařilo se ji však prokazatelně dohledat. Na podzim roku 2017 byla na lokalitě potvrzena i nákaza račím morem.

Do současnosti nebyli na Radotínském potoce žádní jedinci raka kamenáče nalezeni. Bohužel se zdá, že výskyt tohoto kriticky ohroženého druhu na území Prahy je minulostí.

\section{ZÁVĚR}

Hodnocení ekologického stavu drobných vodních toků na území Prahy nevyznívá dobře. V žádném z hodnocených profilů nesplňovaly všeobecné fyzikálně-chemické složky limity pro dobrý ekologický stav. Hodnocení ekologického stavu podle makrozoobentosu zatřídilo sledované profily v lepším prípadě do středního stavu, v horším prípadě do poškozeného stavu.

Hlavním důvodem špatné kvality vody je znečištění živinami, predevším fosforem, který je prričinou eutrofizace vodních ekosystémů. Špatnou kvalitou vody jsou zjevně limitována též společenstva vodních bezobratlých saprobic and ASPT indices [3, 4]. In 2017, macroinvertebrates sampling in Botič was done by Lískovcová [6]. Her evaluation based on individual metrics in profiles below Hostivař Reservoir oscillated between moderate and bad status.

No evaluation of smaller Prague streams that are not water bodies has been done to present day using methods analogical to the evaluation of water bodies. This is the merit of our paper, which besides Rokytka and Botič evaluates also another five streams of stream order 3 according to Strahler. The resulting evaluation as moderate and poor status classes is not surprising. It was presumably not improved even by a deviation from the standard methodology when we evaluated only spring samples that tend to be richer. There are numerous unfavourable impacts on watercourses in urban environment. In this paper we looked in particular at water quality and partly at hydromorphological characteristics. Besides that, urban watercourses experience negative impacts of hydraulic stress [5], dramatic water quality deterioration due to reducing the torrential rain load of sewerage systems [22] or an impact of old environmental burdens [24]. The result of an evaluation of water bodies in the Lower VItava sub-basin based on macroinvertebrates [12] gives a rough comparison of the status of small watercourses in Prague. Only a half of water bodies achieved good status in the ecological quality elements of macroinvertebrates. The second half of water bodies was evaluated as having moderate or poor status.

\section{Astacological research}

When evaluating the presence of crayfish, we need to strictly distinguish between native and alien species. A population of alien species of spiny-cheek crayfish (Faxonius limosus), which has spread to the Czech Republic up the Labe River, has been present in Prague already for several decades. This invasive species usually does not spread to small watercourses but may be actively brought there by people. This risk holds true especially for ponds and water reservoirs. An example of this was Rohožník Pond on Řičanský Stream in Dubeč. The strong local population of spiny-cheek crayfish was suppressed there in 2014 by draining the pond and removing mud from there. Our research was motivated by the aim to find out whether this intervention had been successful. There was an assumption that when the pond was being drained, a large number of specimens could have escaped to Říčanský Stream. Our searching confirmed their presence neither in the watercourse nor in the newly filled pond. The section of the stream below Rohožník Pond is a fast flowing one, which is not a suitable habitat for crayfish. Říčanský Stream is highly polluted by municipal waste water [1] and therefore it is presumably unsuitable even for the invasive spiny-cheek crayfish, which is less sensitive to pollution compared to native crayfish [25]. Even though no crayfish were established when the section was searched, later on the presence of spiny-cheek crayfish was confirmed in Kyjský Pond by a mobile app "Raci v ČR" ["Crayfish in the CR"].

Presence of the alien spiny-cheek crayfish was suspected also in Rokytka. Several spiny-cheek crayfish specimens were found near Podvinný Mill in Libeň in Prague in recent past [J. Patoka, pers. comm.]. Fortunately, when we searched Rokytka on the boundary between Hloubětín and Vysočany did not confirm the presence of spiny-cheek crayfish.

When Šárecký Stream was being searched, the possibility that native Narrow-clawed crayfish (Astacus leptodactylus) may be present there was considered. One specimen of this species was found in the Zlatnice area in January 2015 [J. Svobodová, unpublished]. It was an uncommon discovery of crayfish outside its hiding place in winter, which shows that the crayfish was not in a good condition. Most likely, it may have been a specimen from one of the ponds, perhaps from the nearest one near Dubový Mill. 
v revitalizovaných i prírodě blízkých vodních tocích. Bez důsledného zaměření na kvalitu čištění odpadních vod, včetně odstraňování fosforu, by mohly vyjít naprázdno dlouhodobé snahy pražského magistrátu o zlepšení kvality vody v nádržích i vodních tocích.

\section{Poděkování}

Výzkum byl financován projektem CZ.071.02/0.0/0.0/16_023/0000118 VODA PRO PRAHU a institucionální podporou Ministerstva životního prostředí ČR v rámci naplňováni Dlouhodobé koncepce rozvoje výzkumné organizace VúV TGM na období 2018-2022. Autoři děkují pracovníküm Odboru ochrany prostředi MHMP za vstřicnost při realizaci výzkumu a oběma recenzentům za jejich cenné připomínky, které prispěly ke zkvalitněnípublikace.

\section{Literatura}

[1] Hlavní město Praha. Pražská príroda, http://www.praha-priroda.cz/ [cit. 22.7.2021]

[2] ČESKÝ NORMALIZAČNÍ INSTITUT (1998) ČSN 757221 Jakost vod - Klasifikace jakosti povrchových vod, $20 \mathrm{~s}$.

[3] NÁBĚLKOVÁ, J., KOMÍNKOVÁ, D., ŠŤASTNÁ, G. (2004) Assessment of ecological status in small urban streams of Prague agglomeration. Water Science and Technology 50(5): 285-291

[4] KOMÍNKOVÁ, D., STRÁNSKÝ, D., ŠT̃ASTNÁ, G., CALETKOVÁ, J., NÁBĚLKOVÁ, J., HANDOVÁ, Z (2005) Identification of ecological status of stream impacted by urban drainage. Water Science and Technology 51(2): 249-256

[5] KOMÍNKOVÁ, D. CALETKOVÁ, J., VITVAR, T. (2017) Analysis of environmental flow requirements for macroinvertebrates in a creek affected by urban drainage (Prague metropolitan area, Czech Republic). Urban Ecosystems 20(4): 785-797

[6] LíSKOVCOVÁ, B. (2018) Identifikace zdrojů znečištění podél urbanizačního gradientu drobných toků na základě změny struktury společenstva makrozoobentosu. Dipl. práce, ČVUT v Praze, 131 s. + príl.

[7] HŘEBíK, Š. (2003) Ekologie makrozoobentosu malých vodních toků v CHKO Český kras. Bohemid centralis 26: 53-72

[8] Směrnice 2000/60/ES Evropského parlamentu a Rady z 23. řijna 2000 ustavující rámec pro činnost Společenství v oblasti vodní politiky, 2005. Aktualizovaný pracovní překlad s anglickým originálem. MŽP, Odbor ochrany vod, Praha

[9] SCHMEDTJE, U., COLLING, M. (1996) Ökologische Typisierung der aquatischen Makrofauna. Informationsberichte des Bayerischen Landesamtes für Wasserwirtschaft 4(96): $543 \mathrm{~s}$.

[10] PATOKA, J., BUŘIČ, M., KOLÁŘ, V., BLÁHA, M., PETRTÝL, M., FRANTA, P., KOUBA, A. (2016) Predictions of marbled crayfish establishment in conurbations fulfilled: Evidences from the Czech Republic Biologia 71(12): 1380-1385

[11] ŠTAMBERGOVÁ, M., SVOBODOVÁ, J., KOZUBíKOVÁ, E. Raci v české republice. Agentura ochrany prírody a krajiny ČR. Praha, 2009. 255 s.

[12] Povodí Vltavy, s. p. Návrhy plánů dílčích povodí 2020. https://www.pvl.cz/planovani-v-oblasti$\mathrm{vod} /$ navrhy-planu-dilcich-povodi-2020. [cit. 22.7.2021]

[13] KOŽENÝ, P., BERÁNKOVÁ, T., BOUŠE, E., FIALA, D., JANOVSKÁ, H., MUSIL, J., SVOBODOVÁ, J. Využití umělých a prírodních struktur pro revitalizace a zvýšení biologické a morfologické pestrosti pražských potoků. VúV TGM, Praha. 2018. 43 s.

[14] OPATŘILOVÁ, L., KOKEŠ, J., NĚMEJCOVÁ, D., SYROVÁTKA, V., ZAHRÁDKOVÁ, S., MACIAK, M. HORKÝ, P. Metodika hodnocení ekologického stavu útvarů povrchových vod tekoucích pomoc biologické složky makrozoobentos. VÚV TGM, MŽP ČR. Praha. 2011. 24 s.

[15] ROSENDORF, P. Metodika hodnocení všeobecných fyzikálně-chemických složek ekologického stavu útvarů povrchových vod tekoucích. VÚV TGM, MŽP ČR, Praha. 2011. $20 \mathrm{~s}$.

[16] KOKEŠ, J., NĚMEJCOVÁ, D. Metodika odběru a zpracování vzorků makrozoobentosu tekoucích vod metodou Perla. VÚV TGM, 2006. 10 s.

[17] ČESKÝ NORMALIZAČNÍ INSTITUT (2008) ČSN 757701 Jakost vod - Metodika odběru a zpracován vzorků makrozoobentosu tekoucích vod metodou PERLA, $16 \mathrm{~s}$.

[18] MŽP ČR. Protokol odběru - tekoucí vody, https://www.mzp.cz/cz/prehled_akceptovanych_ metodik_tekoucich_vod [cit. 22. 7.2021]

[19] Vyhláška č. 49/2011 Sb., o vymezení útvarů povrchových vod

[20] LANGHAMMER, J., HARTVICH, F., MATTAS, D., ZBOŘIL, A. Vymezení typů vodních toků. PřF UK v Praze. $2009.29 \mathrm{~s}$.
The finding of Narrow-clawed crayfish in Dalejsky Stream at the upper boundary of the Řeporyje municipality is gratifying but not surprising. The site is located close to the former Řepora open air museum in whose ponds Narrow-clawed crayfish has been found [26]. However, its greater spreading further downstream is presumably hindered by the municipal pollution of Dalejský Stream below Řeporyje.

Perhaps the most significant negative finding of the astacological research is that the population of stone crayfish (Austropotamobius torrentium) in Radotínský Stream has become extinct. In the past, stone crayfish used to be present long-term in an approximately one-kilometre-long section above the Choteč municipality up to Radotín, i.e., roughly in five kilometres of Radotínský Stream [26]. The best situation occurred in 2010 when crayfish abundance amounted to over 60 crayfish in the section. Over time, their abundance started to decline, e.g., in 2014 there were only 13 crayfish per 100 suitable hiding places [26] but the population was still stable.

As described in the chemical analyses results, the Radotínský Stream basin is affected by a strong municipal waste water load. As shown by accidental findings as well as inspections of the state of the watercourse above the monitored site, the degree of its treatment ranges from very low to being in serious disrepair. An accidentally captured water sample from Radotínský Stream in Tachlovice (approximately $7 \mathrm{~km}$ above the monitored profile) on 14/9/2017 provides evidence of episodic statuses incompatible with the lives of a majority of aquatic organisms (dissolved oxygen content $2 \mathrm{mg} / \mathrm{l}$, ammonia nitrogen $\left.8.15 \mathrm{mg} / \mathrm{l}, \mathrm{BOD}_{5} 47 \mathrm{mg} / \mathrm{l}\right)$ [P. Kožený, unpublished].

The poor water quality in Radotínský Stream was also looked into by the staff of the state-owned enterprise Povodí VItavy. In 2017, blackish turbid water was repeatedly established in the stream below Tachlovice over the course of approximately 14 days [Mr. J. Válek, pers. comm.]. Its source was presumably a malfunctioning waste water treatment station in the source area but it was not provably traced. In autumn 2017, crayfish plague was also confirmed in the site.

No stone crayfish specimens have been found in Radotínský Stream to present day. Unfortunately, it seems that the presence of this critically endangered species in Prague is a thing of the past.

\section{CONCLUSION}

The outcome of the evaluation of the ecological status of small watercourses in Prague is not positive. None of the evaluated profiles met general physicochemical quality elements limits for a good ecological status. An evaluation of the ecological status according to macroinvertebrates classified the monitored profiles as moderate status at the best and as poor status at the worst.

The main reason for the evaluated poor water quality of small watercourses is pollution by nutrients, in particular phosphorus, which causes eutrophication of aquatic ecosystems. Poor water quality clearly limits also the populations of aquatic invertebrates in restored and semi-natural watercourses. Without a consistent focus on the quality of waste water treatment including phosphorus removal, the long-term efforts of the Prague City Hall aimed at improving water quality in reservoirs and in watercourses may prove futile. 
VTEI/ 2021/ 5

[21] Vyhláška č. 395/1992 Sb. Vyhláška Ministerstva životního prostředí České republiky, kterou se provádějí některá ustanovení zákona České národní rady č. 114/1992 Sb., o ochraně přírody a krajiny [22] DURAS, J. Lovci tornád po česku. Limnologickénoviny 2021(2): 2-12

[23] WANG, L. Z., ROBERTSON, D. M., GARRISON, P. J. (2007) Linkages between nutrients and assemblages of macroinvertebrates and fish in wadeable streams: Implication to nutrient criteria development. Environmental Management 39(2): 194-212

[24] KREJČOVÁ, L. (2013) Kvalita vody v pražských potocích. Bak. práce, PřF UKv Praze, Praha. 45 s.

[25] SVOBODOVÁ, J., DOUDA, K., ŠTAMBERGOVÁ, M., PICEK, J., VLACH, P., FISCHER, D. (2012) The relationship between water quality and indigenous and alien crayfish distribution in the Czech Republic: patterns and conservation implications. Aquatic Conservation-Marine and Freshwater Ecosystems 22(6): 776-786

[26] Agentura ochrany prírody a krajiny ČR. Nálezová databáze ochrany prírody: http://portal.nature.cz [cit. 22. 7. 2021]. On-line databáze. Archivuje Odbor monitoringu biodiverzity AOPK ČR, Praha

\section{Autoři}

\section{Mgr. Pavel Kožený}

凶pavel.kozeny@vuv.cz

ORCID: 0000-0002-6091-4205

RNDr. Hana Janovská

凶hana.janovska@vuv.cz

ORCID: 0000-0001-7259-1418

RNDr. Jitka Svobodová

凶jitka.svobodova@vuv.cz

ORCID: 0000-0002-4811-503X

Výzkumný ústav vodohospodářský T. G. Masaryka

Příspěvek prošel lektorským řízením.

DOI: 10.46555/VTEI.2021.07.005 